ACID-BASE REACTIONS AND KINETICS
OF THE HALATES IN PUSED NITRATES

By

James Max Schlegel

P. R. Duke

November 1962

Ames Laboratory

Iowa State University Ames, Iowa

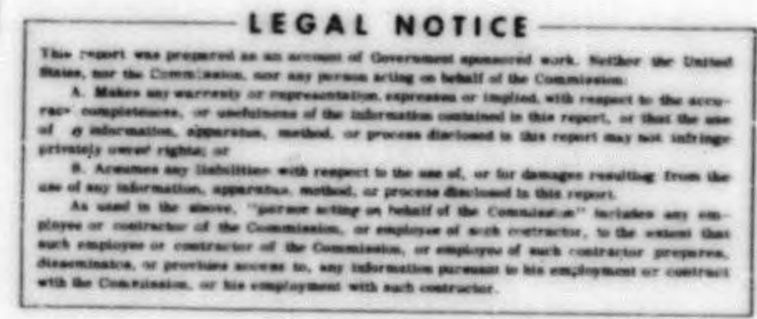


F. H. Spedding, Director, Ames Laboratory.

Work 'performed under Contract No. W-7405-eng-82.

1 
TABLB OF CONTENTS

Page

ABSTRACT .................... iv

INRRODUCTION . . . . . . . . . . . . . . 1

LIERATURE REVIEW. . . . . . . . . . . . . 5

SXPERIMENTAL INVESTIGATION . . . . . . . . 8

Katerials and Apperatus. . . . . . . . . 8

Procedure. . . . . . . . . . . . . . 9

Solub1l1ty heasurements. . . . . . . . 12

EXPERIKENTAL RESULTS . . . . . . . . . . 17

The Bromete Reaction........... 17

The reaction and mechanism . . . . . . 17

Tempers ture dependence . . . . . . . . . 24

Solvent effects. . . . . . . . . 28

The Chlorete Reection. . . . . . . . . 31

The reaction and mechenism. . . . . . . 31

The chlorlde effect. . . . . . . . . . 35

A new mechan1sm. ............ 40

Temperature dependence . . . . . . . 46

Whe Iodate Reaction. ........... 4 ?

Preliminary studies. . . . . . . . . 47

The nitrete reaction......... 48

The mechanlsm. . . . . . . . . . 51

CONCLJSIONS AND SULMARY. . . . . . . . . . 56

BIBLIUGRAPHY . . . . . . . . . . . . 62 


\section{ACID-BASE REACTIONS AND KINETICS OF THE HALATES IN FUSED NTTRATES"}

Jaines Max Schlegel and F. R. Duke

\section{A.BSTRACT}

The mechanist of the reactions of the halates, bromate, chlorate, and lodate, w1 th dichromate in fused alkall nitrates has been shown to 1nvolve a rast equilibrium followed by a slow rate determining step to glve oxygen and halogen gases as rinal proâcts :

$$
\begin{aligned}
& \mathrm{Cr}_{2} \mathrm{O}_{7}^{\mathrm{I}}+\mathrm{XO}_{3}^{-} \rightleftharpoons \mathrm{XO}_{2}^{+}+2 \mathrm{COO}_{4}^{\mathrm{a}} \text { fest } \\
& \mathrm{XO}_{2}^{+}+\mathrm{X}^{-} \longrightarrow \text { Produets slow }
\end{aligned}
$$

Barium 1on was aded to prec1pitate chromate 10 and displace the equilibrium. The rate step for the bromate reaction involves a unimolecular decomposition of bromyl $10 \mathrm{n}, \mathrm{BrO}_{2}^{+}$. The rate step for the other halatea involves the oxidation of a hallde $10 \mathrm{n} \mathrm{by}$ the interaediate $10 \mathrm{n}, \mathrm{XO}_{2}^{+}$, as shown in the second equation above. The equilibrium step is the same for all three halates. From the values of the equilibrlum constants, the relative aclaty of the intermediate $10 \mathrm{~ns}, \mathrm{XO}_{2}^{+}$, in the presence of dichromate are

$$
\mathrm{BrO}_{2}^{+}<\mathrm{IO}_{2}^{+}<\mathrm{ClO}_{2}^{+} \approx \mathrm{NO}_{2}^{+}
$$

Previous attempts to separate the equilibrium constant and the rate constant alrectly for the dichromate-nitrate reaction have

This repont is based or a Ph.D. thesis by James Max Schlegel submitted November, 1962, to Iowa State University, Ames, Iowa. This work was done under contract with the Atomic Energy Comaission. 
been unsuccessful. However, in these attempts lesd 1on was used to preclpitate the chromete 1on, and leed 1 on reduces the activity of dichromate and bromide by forming complexes. Replacing the lead Ion with berlum 1on, these constants were seperated, thus making 1 t possible to compare the nitryl lon with the other. Intermedite 1ons.

The subsequent decomposition following the fast equillbrium step has not been corpletely characierized for the chlorete reaction. The intermediste acla $10 \mathrm{n}, \mathrm{C}_{2} \mathrm{O}_{2}^{+}$, appess to catalyze the decomposition of chlorate. However this decomposition occurs at a isster rete then the slow step postula ted above and therefore does not appear in the rate expression at high concentrations of chlorste and chloride. A rough scale of stablilty of the intermediate 1ons, $3 \mathrm{rO}_{2}^{+}<\mathrm{IO}_{2}^{+}<\mathrm{NO}_{2}^{+}$, was obtalned by compar1ag the rate constants at one temperature. 


\section{INTRODUCTION}

Frevious to 1900 , 1nvestigetions of fused salt oystems had been uncertaken nelnly because of the1r novelty. At that t1we Leasurements were very approximate. Results of a higher order of accuracy were obtained between 1920 and 1950. General1zotions were made w1th an attempt to systemat1ze the study of fused salt systems. After 1950 work progressed to deterwine exact values of the physical propertieg of fused electrolytes. Among these properties one might lnclude density, conductivity, viscosity, vepor pressure, compressibil1ty, surface tension, anci. trancport number. Presently there are not wany good alrect methods to investigate the structure of fused electrolytes, although several attempts have been wade through $\mathrm{x}$-ray end neutron diffraction studies (1), and spectrophotometric studies (z). Consequently, the chemist hes resorted to a study of the various physical properties nentioned above in hopes thet correletions end relationships between these properties w1ll be self consistent with 2 proposed toâel.

An Insight into the structure of fused salts or fused electrolytes wight elso be gained by studying reactions carried out in this medium. The course of certain cheracteristic reections is deternined largely by the nature of the solvent. Excluaing oxidation-reduction reactions, the structure of seversi nonaqueous solvents has been devaloped by studylng 
reactions carried out in these solvents (3).

The behavior of many aclâ-base reactions has been characterlzed in other solvents ns well as in water. The more feullier solvents are amonis, acetic scid, snd hydrogen fluoride. Using a fused electrolyte os the solvent one cen study the dechanisins of acli-bese reections beyond the one hundrea degree limit lnposed by water. Also, one can study these reactions in the absence of hycolysis and solvetion by the solvent, both of whlch usuelly introduce severel complex reactions finto the mechenism.

The 1noreasing technolog1cal 1mportance of high temperature processee has stirred \& greet interest in the rield of reactions of fused electrolyies. The manufacture of glass, cement, end cerainie products, the formation or sleg in blast furneces, the use of ammonium sulfate and ammonium fluoride as eluxes in the opening of ores involve reactions at high temperetures between metal oxides, sulfides, and halides. The Lewls concept of aclas ond boses has been successfully epplied to these reactions. In 1938 Lux (4) proposed an acid-base definition wich is actuelly a part of the more general Lewis theory. According to Lux, an equilibrium,

$$
\text { Base } \rightleftharpoons \mathrm{Asid}+\mathrm{O}^{\approx} \text {, exists. }
$$

When an acid reacts with a base there is a transier of oxide 10n. The result is the familiar conjugate acid-baso syster. When two aclas are in the presence of a base there is a 
conpetition for oxide lon. The predominant reaction w1ll be between the base and the stronger ocla, the latter belng the better oxide acceptor. Obviously this âfinition 18 limited because it exciudes analogous reactions of sulfides and halides. However a great many solvent systems in use are oxices or involve oxyanions. Flood and Forlend (5) compared acic strengths of oxide systems by comparing volues of the equilicrium constant,

$$
K=\frac{A_{a c i d} A_{0}=}{A_{\text {bese }}}
$$

The research that has been done to characterlze the reactions of fused salts has been the study of the decomposition of fused oxides and severgl pure sslts. Only recently ave reactions been conducted in fused electrolytes. usling the fused salt as a solvent. Yamamoto (6) has compared the relative aclaity of the oxyanions, dichromate and pyrosulfate, and several metal lons in fused alkall nitrates. In tnis case, nitrate played the role of the solvent as well as the base. Studies conducted by Duke and Lawrence (7) 1ncicete that bromate is a much stronger base than nitrate. Dichromete is a very weals acid. Perhaps the reaction between dichromate and bromate, as well as the other halates, could be studied in fused alkali nitrates. The purpose of tris study is to characterize the reactions between the hajates and dichromate in alkall nitrates and to compare the 
relative strength and stablilty of the halates in the presence or dichromate. 


\section{LITERATURE REVIEW}

Varlowe Iverson ( $(8)$ observed the reaction between nitrete and dichromate when stuaylrg lead chloride complexes in a eutectic mixture of sodium ana potassium n1trate. Upon adảng chlorlue and cromide and varylng the concentration of lead nitrate, he concluded that the following equilibrium existed in fused nitrates:

$$
\mathrm{NO}_{3}^{-} \rightleftharpoons \mathrm{NO}_{2}^{+}+\mathrm{O}^{--}
$$

When dichromate is adaed, 1.t accepts the oxide ion from nitrate and forms chromate.

$$
\mathrm{Cr}_{2} \mathrm{O}_{7}^{--}+\mathrm{NO}_{3}^{-} \rightleftharpoons \mathrm{NO}_{2}^{+}+2 \mathrm{CrO}_{4}^{--}
$$

The nitr:i ion then combines with a nitrate or a hallde ion and decouposes to products of which nitrogen doxide is a firal product. The above equilibrium 11 es far to the left and no resction is o'bservea unless lead ion is added to precipitate the chromete. Tise equilibriun constant for the above reaction is very stall, approximately $10^{-14}$. Even when lead 10n is added, the consentration of nitryl fon is not large enough to allow separation of the equilibrlum constant and rate constant. That 1s, the reaction appears to be first order in the disappearance of dichromate and not total acid,

$$
\mathrm{T}_{\mathrm{a}}=\mathrm{Cr}_{2} \mathrm{O}_{\mathrm{r}}^{--}+\mathrm{NO}_{2}^{+}
$$

Duke end Yamanoto (9) were able to separate these two constants and evaluate the rate constant for the reaction,

$$
\mathrm{NO}_{3}^{-}+\mathrm{NO}_{2}^{+} \rightarrow \text { Products }
$$


by adaing a stronger acid, pyrosulfate. The seme rate deterwinlig step occurs es when dichromete reacts with nitrete. When one substituies the rove constant obtalned from the pyrosulfate rsaction, the equilioritu constant for the dichromate reaction can be determined. The flow rate of the ges for each ruction wist be natched carefully since 1 t hes been shown that the rate or aecomposition 1nvolving nitrste varles as the flow rate of the carrier gas $1 \mathrm{~s}$ changed. Apparently the gaseous product, nitrogen pentoxide, is quite soluble in fused nitrates and the rate deteruining step is the rate at which geseous nitrogen pentoxide diffuses to the surface of the melt. By assuming that the same equilitrium exists when metal 10..s are used as the acid, Yememoto (6) evalueted their relative acidity. In this ease, he obtalned a product of constents and used the rate constant from the pyrosulfate reaction to determine the equiliorium constants for the metal 1ons. The relative strengths of the acics in the order of increas1ng acid strength ere: $\mathrm{Cr}_{2} \mathrm{O}_{7}^{--}, \mathrm{Zn}, \mathrm{Cu}, \mathrm{S}_{2} \mathrm{O}_{7}^{--}$. When Duke and Lewrence ( 7 ) studied the reactions of the same metal ions With bromate in fused alkall nitrates, they found 1 t necessery to postulate a metal-bromate complex formation with subsequent decomposition. Bromete is a much stronger base than nitiate in fused nitrates, such that the reaction of bromete with mutal lons takes place before much, 1f any, nitrate has reacted. Anelysis has shown thet no oxides of nitrogen are 
present in the geses evolved. The pote of decomposition is hichly dependent on the metel $10 \mathrm{n}$ used, which is expla1ned by a wetsl-cromete complex formotion. The equllibrium constant oI Metel lons with nitrete 18 not obtalned independently; therefore, the reletive ec1dity of zinc and copper lons to dichromste and pyrosulfate is not estaclished.

Exuensive studies of the dichromate reaction using barlum as the prec1pitating agent have not been done. It has been skown thet barium works just as successfully as leed in promoting the reaction between dichromate and nitrate. However the csrium chrotute precipltete does not settle very rapidly, wakirg. it dificult to extrect and anelyze semples from the welt Gurlng the course of a reection. But one cen follow the eppeepsence of gaseous products and relote this to the disappearance of one of the reactants, namely that reactent which is adced in libiting concentration. If one assumes that berlum does not form complexes with any of the lons in solution, 1t would be interesting to 1nvest1gate the reactions between aichromate and halstes in fused nitrates. 


\section{EXPERINENTAL INVESTIGATION}

\section{A. Naterials and Apperatus}

All the chemicals used in this study were A.C.S. Reagent Grade. They were arled at $110^{\circ} \mathrm{C}$ in an oven and then 8 tored in a desiccetor until needed. The constent temperature bath consisted of an insulated ten quert enacel pot filled w1th a mixture of molten potassium and sodiun nitrete. The primary heat was supplied by a ten inch Cromalox 1500 watt ring heater recessed in flre briciss ond connected to a 220 volt Varalc. The auxiliary heater was on alumdum core wrapped with nlchrome wire and coated with Sauereisen. This heater was connected to a Brown Electronik Temperature controller whlch was mon1 tored by a chromel-alumel thermocouple. The temperature was kept well within $\pm 2^{\circ} \mathrm{C}$ of the desired temperature. A one-half 1nch transite cover was fitted on top of the enamel pot to prevent radient loss of heat.

The reactions were carried out in a reaction vessel conscructed so as to continualy purge the solution with an 1nert carrier gas, to stir the solution, and to efforâ easy sampling of the eolution with a preheated p1pet. Th1s vessel was made of $34 \mathrm{~mm}$. pyrex tubing $w 1$ th $834 / 45$ standara taper joint at one end aná closed at the other end. The overall length was $24 \mathrm{~cm}$. The top of the reaction vessel was a standard taper joint with a gas inlet and a gas outlet. The inlet extended 
to w1thin $1.5 \mathrm{~cm}$. of the bottom of the tube. The outlet was connected to a manifola equipped to supp...y six sulfite scrubbers. The sorubbers were w1de moutil erlenmeyer flasics. A large test tube with a small hole in the bottom was inserted 1nto the mouth of the erienmeyer rlask. Th1a test tube was f1lled w1th smill glass beads to afford af lerge surface area contact for the halogen gases to be reduced. A schematic arawling of the apparatus is 11lustreted in Figure 1.

The carrier gas, nitrogen, was drled by passing the gas through a magneslum perchlorate tower and metered by an or1flce teter. The meter was callbrated witi a "precision" wet test meter. The flow rate of the carrier ges was 0.2111 ters per tolnute for most of the runs. Occasionally, the flow rate was 1 ncreased to 0.4011 ters per minute to see what effect this increese had on the reaction rate. The reaction rate was Independent of the flow rate for all seactions studied in this thee1s.

\section{B. Procedure}

Two wethods can be used to study reaction rates in fused salts. The concentration of a reactan: can be followed with time by sampling the melt with a prehested plpet and letting the semple solidify on a cold porcelain plate thereby quenchIng the reaction. Or, the disappearance of a reactant can be meesured by following the appearance of one of the product 


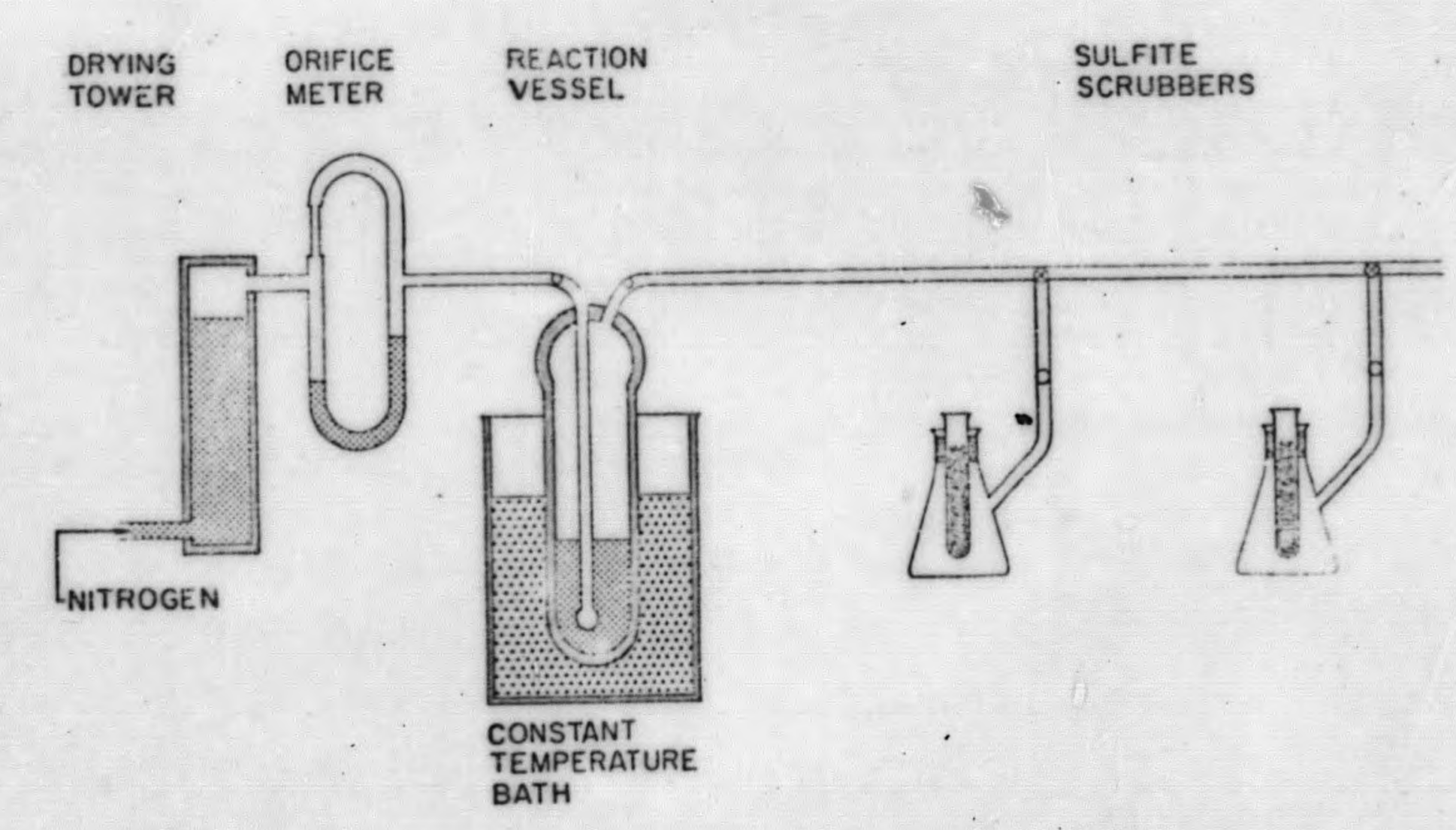

F1gure 1. A schematic drewing of the apparatus used to study the reactions of the halates $w 1$ th dichromate 
gases, provided the stolchlometry is known. Since the precipltate of berlum chromate is so widely alspersed and does not settle rapldy, 1 was found best to use the latter procedure in this study.

Lre desired mlxture of selts to be used as the solvent was fused and all cut one of the reactants were welghed, placed in the melt and allowed to $\mathrm{m} 1 \mathrm{x}$. This solution was purged w1th the inert carrier gas, n1trogen, for one-half to one hour to allow complete alssolution of the reactants and sweep out any water dissolved in the meit. When a run was to be made, the last constituent wes added and halogen gases were collected in sulfite scrubbers and reduced to hallde ion. The heilde was then titrated with silver nitrate using elther eosin or âlchloroflouresceln as an indicator, depending on which ruaction was beling stuảeâ (10). An aciâ solution of sulfite, prepared by bubbling eulfur dioxide through water, was used to collect bromine from the bromate reaction. These solutions could be directly titrated with silver nitrate. In the chlorate reaction a solution of sodium sulfite was used. But chloride can not be titrated in a neutral solution of sulf1te because the sulfite bleaches the 1nalcator. Therefore each solution was aclalfled and allowed to steam on a hot plete to drive off all of the sulfur dioxide. Base and acetate were added to neutralize the acid and to keep the solutions at approximately the same pH. A blank was run and all 
samples were titrated to the saime end point. The reactions were allowed to go to completion and the total amount of halogen evolvea was taken as the 1 intial amount of reactant Edđeâ. Each sample was subtracted from th1s number to obtain the concentration of reactant at the t1me recorded for that sample. At first all the numicers were converted to the absolute concentration of cromate or dichromate; however one is only iriterested in the slope. Therefore the number of mill1liters or silver nitrate was plotted directly on sem1-log japer. All of the vaiues for $k^{\prime}$ except those for the dichromete-bromate and the dichromate-nitrate reactions should be multiplied by the constant, 2.3 , because the $k^{\prime}$ values reported were oitalned from a common log plot. This conversion is not necessary unless one is interested in the rate of the reaction. The rate of the reaction $1 \mathrm{~s}$ not of primary interest in this study and the rate is independent of the equilibrium constart. Concentrations are expressed in woles per 1000 grams of solvent unless otherwise inalcated. In the chlorate reciction the number of grams of chlorate added was quite lerge. Consequently sodium chlorate was incorporated as part of the sclvent.

\section{Solub1lity Messurements}

The solubility of barium chromate was determined in alkali nitrates and chlorates. It is necessary to know the 
colublifty of barium chromate in the solvents used before the equilibrium constants of the reactions can be caiculated. The velue ootalned for the solubility of bprium ohromete in a eutectic mixture of sodium and potasium nitrate at $250^{\circ} \mathrm{C}$ wes reproducible and was in agreement with the value obtained by Duke and Iverson (11). However the values obtained in a 50-50 wole percent $\mathrm{NaClO}_{3}-\mathrm{KNO}_{3}$ mixture were not precise. Barium chromste does not settle easily in this mixture. After one week small amounts of suspendad particles were present in the supernatent liquid. The lower limit of the values obtained was talien as the sollibility. This number, $\mathrm{K}_{\mathrm{sp}}=2 \times 10^{-6}$, is relatively close to the value obtalned for potessiun-sodium nitrate. This is apparent because sodium chlorate-potassium nitrate forms a reclprocel salt mixture and the solubility in sodium-potassium nstrate solvent appears to be independent of the mole fraction of the solvent cations.

The chromate conventration was sufficiently low to determine the solubility colorlmetrically. The analysis was performed using the diphenyle arbizide method (12). The soiutions were prepared by fusing one hunared grams of a mixture of sodium and poissium nitrate in a test tube and adding an amount of carlum nitrate equivalent to the concentrations used In a typloal rux. Exactly 0.10 mole per 1000 gms. of solvent of potassium chromate was adaed. The mixtures were stirred for epproximately thirty minutes and ollowed to settle. The 
mixtures were kapt at the desired temperature overnight before sampling. Samples were witharawn from the supernetant liquid with a prehosted pipet and allowed to cool. The two to three grom semples were welghed end dissolved in $3 \mathrm{~N}$ HOL. The 1ndcetor was added and the samples were diluted to $100 \mathrm{mls}$. After five minutes the chrodete concentration was messured with a Junior Coleman Spectrophotometer and the concentration detemined from a staniard curve. Two different concentrations of berium nitrste were used and the solublilty determined from $S=\sqrt{\left[\mathrm{sa}^{++}\right]\left[\mathrm{CrO}_{4}^{*}\right]}$. The cation ratios were $38 / 62,50 / 50$, and $60 / 40$ wole percent $\mathrm{K} / \mathrm{lla}$. The temperatures were $249^{\circ} \mathrm{C}, 259^{\circ} \mathrm{C}$, ana $k 39^{\circ} \mathrm{C}$. The results $\varepsilon$ re shown in Table 1 .

The solubility is tenperature aependent, ard a plot of Loz (solubility) versus $1 / \mathrm{T}$.gives a reasonably stralght line (aigure 2). The solubility appers to be independent of the wole percent of the cations in the solvent.

Table 2. Soludilites of barium chromete at several temperatures in mixtures of sodium and potassium nitrate

\begin{tabular}{lll}
\hline Teap. So & Solub1l1ty product & Solub1lity \\
\hline $259^{\circ}$ & $4.00 \times 10^{-6}$ & $2.00 \times 10^{-3}$ \\
$249^{\circ}$ & $3.20 \times 10^{-6}$ & $1.79 \times 10^{-3}$ \\
$238^{\circ}$ & $2.40 \times 10^{-6}$ & $1.55 \times 10^{-3}$ \\
\hline
\end{tabular}

aThese values are the average of values obtalned at three different berlum concentretions and using three different mole percent mixtures of sodium and potassium nitrate. 


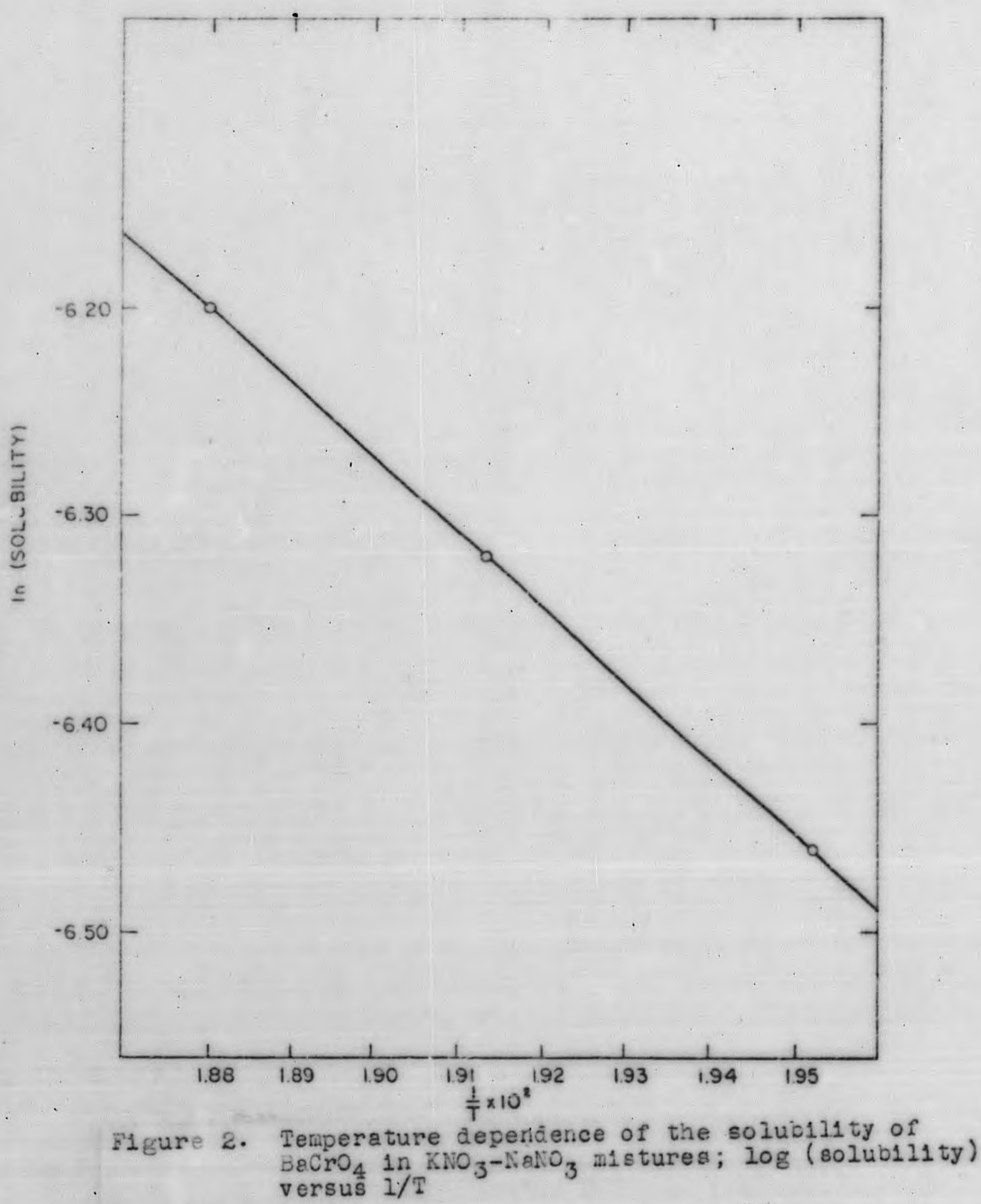


The soluoll1ty of barlum chromete in $\mathrm{NaClO}_{3}-\mathrm{KNO}_{3}$ a.1 xture 1s $0.002 m \pm 0.002 m$. The results are very close to those obta1ned in sodium and potaselum nitrete solvent. Iverson (8) has shown that other lons present in the delt have little elfect on the solubility of bar1um chromate. Therefore the eculilorium corstants for all the reactions were evaluated usling the solubility obtained in sodium-potassiun nitrate a1xtures. 
IV. EXPERTLENTAL RESULTS

\section{A. The Bromete Reaction}

\section{Tho resction and mechen1sm}

The reection between dichromete end bromete was 1nvest1gated to see if the bromyl 1on, enslogous to the nitryl 1on, 1s formed in the absence of any wetal fons which might form complexes. Barium nitrate was used as the precipitating ogent because it was thought thet barlum would not likely form couplexes w1th any of the lons in solution. D1chromete wes used as the sold. Although dichromete w1ll react w1th Mtrate in the presence of barlum, it w1ll be shown that the equilibrium conetent for the formation of nitryl ion is a factor of $10^{5}$ times less than the equilibrium constent in-. volving the forwation of bromyl 1on. Therefore the reaction between bromate and dichrosite w1ll be complete before much, 11 iny, nitrate hes reacted. Lawrence (13) observed the cecomposition of browate to bromide ena oxygen if bromate was sllowed to sit in fused nitretes for several days. Shute (14) has shown that this deconposition is cetsiyzed by bromide. The solutions used in this investigation were analyzed before and after the reaction and no cromide was lound in the melt.

Preliminery runs were conducted. An 1 mediate prec1p1tate of barium chromate with the evolution of bromine was 
18

obeerved. Analysis of the zases evolved showed' no oxldes of nitroen. The reation was somplete within one-helf hour to two hours depending upon the smount of berlum nitrete present. whis dependence of the rate on oerlum lindicates 2 fast equi11brium between dichromste and bromate. When there was no detectable odor of bromine the reection wes ellowed to proceed for enother helf-hour to 1 neure completion of the restion. The resction 18 first orier in the disappesirence of total browate. A typles plot is shown in Figure 3 .

A wechenism to explein these observations 1nvolves s fest eciulicrium followed by a unimolecular desompostion of the bromyl 10n.

(a) $\quad \mathrm{Cr}_{2} \mathrm{O}_{7}^{\#}+\mathrm{BrO}_{3}^{-} \rightleftharpoons \mathrm{BrO}_{2}^{+}+2 \mathrm{CrO}_{4}^{a}$ rest

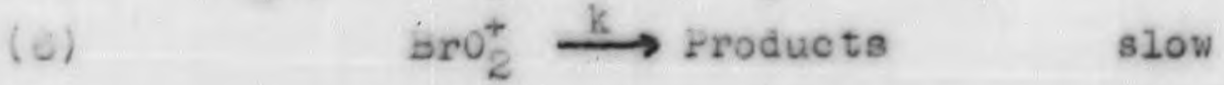

When one messures the diseppecrence of bromste chemleslly, 1t 18 necessary to consicer this messurement as the loge of totel crowete,

$$
\mathrm{T}_{\mathrm{BrO}_{3}}=\mathrm{BrO}_{3}^{-}+8 \mathrm{rO}_{2}^{+}
$$

12 there 18 en apprecisble swount of $\mathrm{BrO}_{2}^{+}$present. If one usea the solubility proauct expression for beriun chronate ond ecuetions 5, 6, snd 7, end wekling the proper substitutions, the rete expression cor. be written,

(8)

$$
\mathrm{A}=\frac{\mathrm{kK}\left[\mathrm{Cr}_{2} \mathrm{O}_{7}\right]\left[\mathrm{Ba}^{++}\right]^{2}}{\mathrm{~K}\left[\mathrm{Cr}_{2} \mathrm{O}_{7}^{-7}\right]\left[\mathrm{Ba}^{++}\right]^{2}+\mathrm{k}_{\mathrm{sp}}^{2}} \mathrm{~T}_{\mathrm{BrO}_{3}}
$$




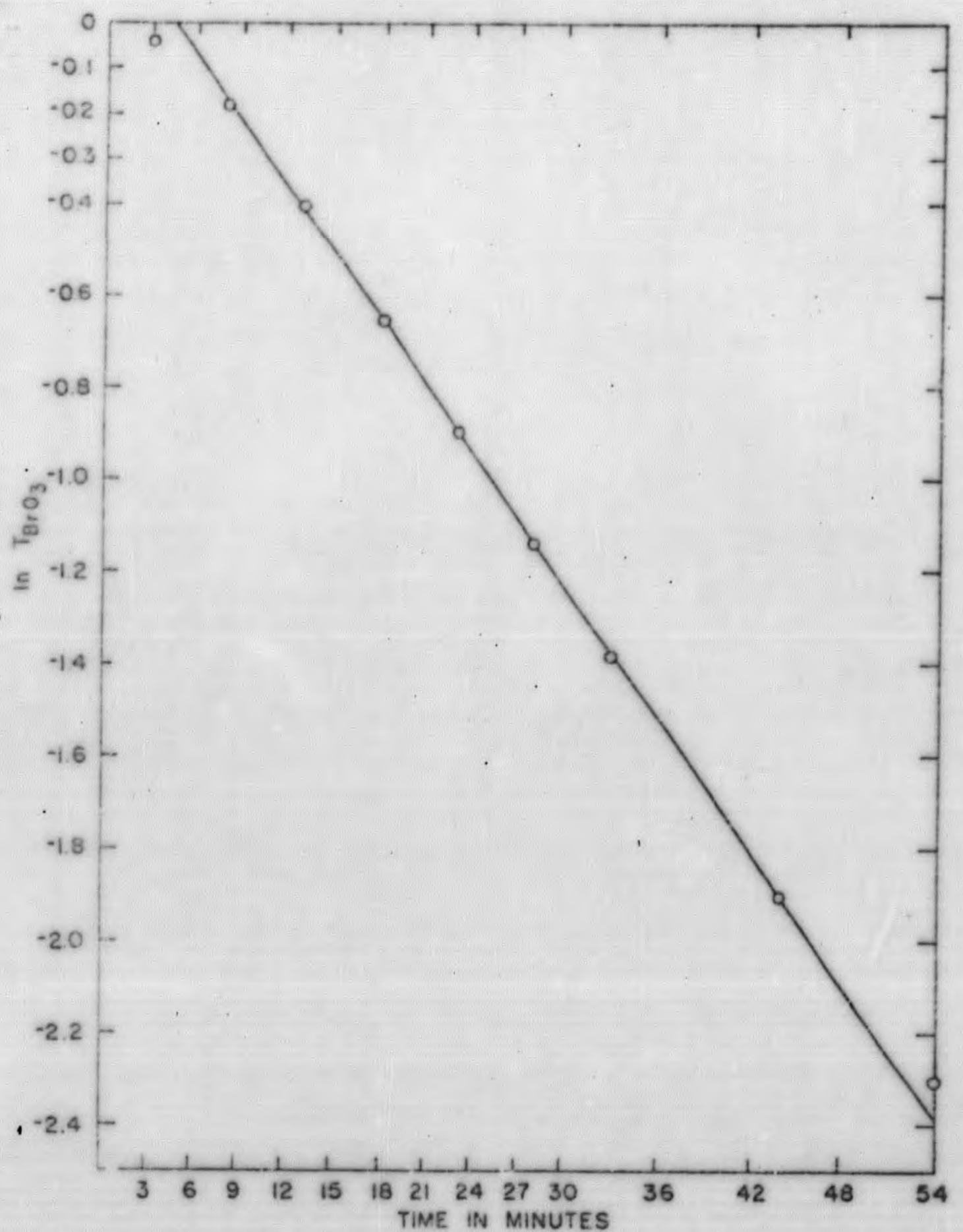

F1 gure 3. Verlation of $\log \mathrm{T}_{\mathrm{BrO}_{3}}$ w1 th tide for a typleal run at $250^{\circ} \mathrm{C}$ in $\mathrm{NeNO}_{3}-\mathrm{KNO}_{3}$ solvent 
All concentrations ere dede large conpered to bromete and are assumed to rease constant throughout a run. Thus,

$$
\text { Rete }=k^{\prime} \mathrm{T}^{\mathrm{BrO}_{3}}
$$

where the pseudo f1rst orcer rote constent 1s,

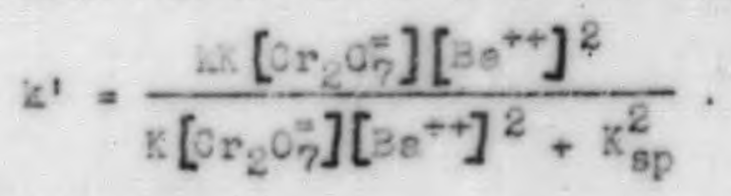

The reelprocen of $k^{\prime} 18$,

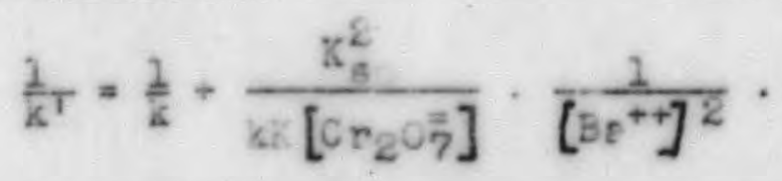

h plot of $1 / \mathrm{K}^{\prime}$ versus $2 /\left[\mathrm{Be}^{++}\right]^{2}$, ss shown in Flgure 4 , eives c streight line with 8 non-zero 1 intercept. The ordinate intercept gives the rate constant directly. W1 th a knowledge of the solubility of berlum chrotete snd the concentretion of bianrowte, the equilibriuk constent can be obtalned from the sbsclssa intercept. The solubility of bariun chromete and its teaperature dependence sre diecussed in Section III.

The Mrst order dependence in totel brohete lmplies uniwolecular alecomposition of bromyl $10 \mathrm{n}, \mathrm{BrO}_{2}^{+}$. The einel products tre bromine snd oxygen. There ore no lons av81lable for sroul to reect with except the solvent, nitrete. However en snelysis of the proluct geses shows no oxides of nitrogen. Therefore a possible mode of decomposition would be,

$$
\mathrm{BrO}_{2}^{+} \longrightarrow \mathrm{Br}^{+}+\mathrm{O}_{2}
$$

snd $\mathrm{Br}^{+}$ploks up en electron and eventually forms bromine. work on the salts of $\mathrm{Br}^{+}$has been reviewed by Klelnberg (15) 


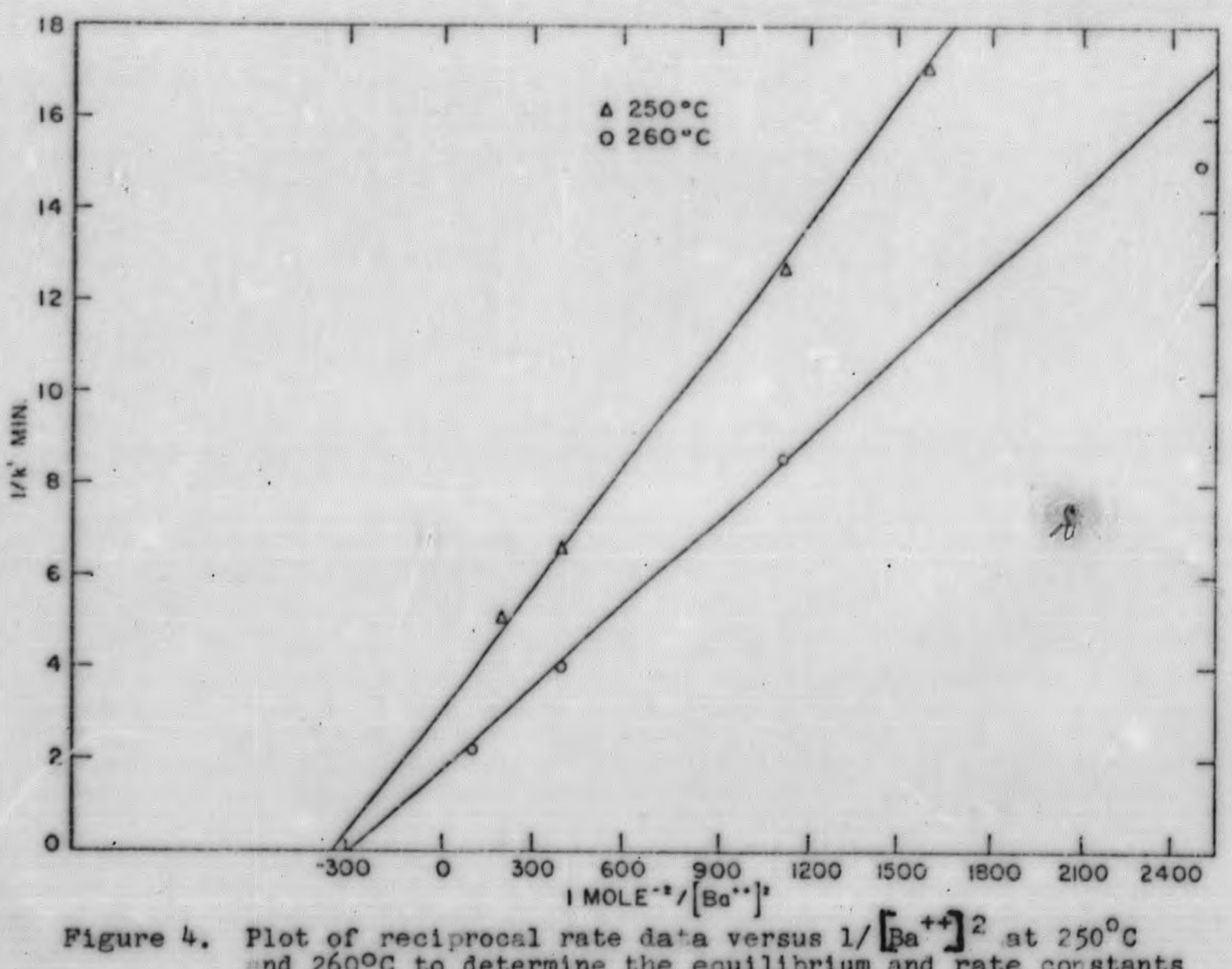




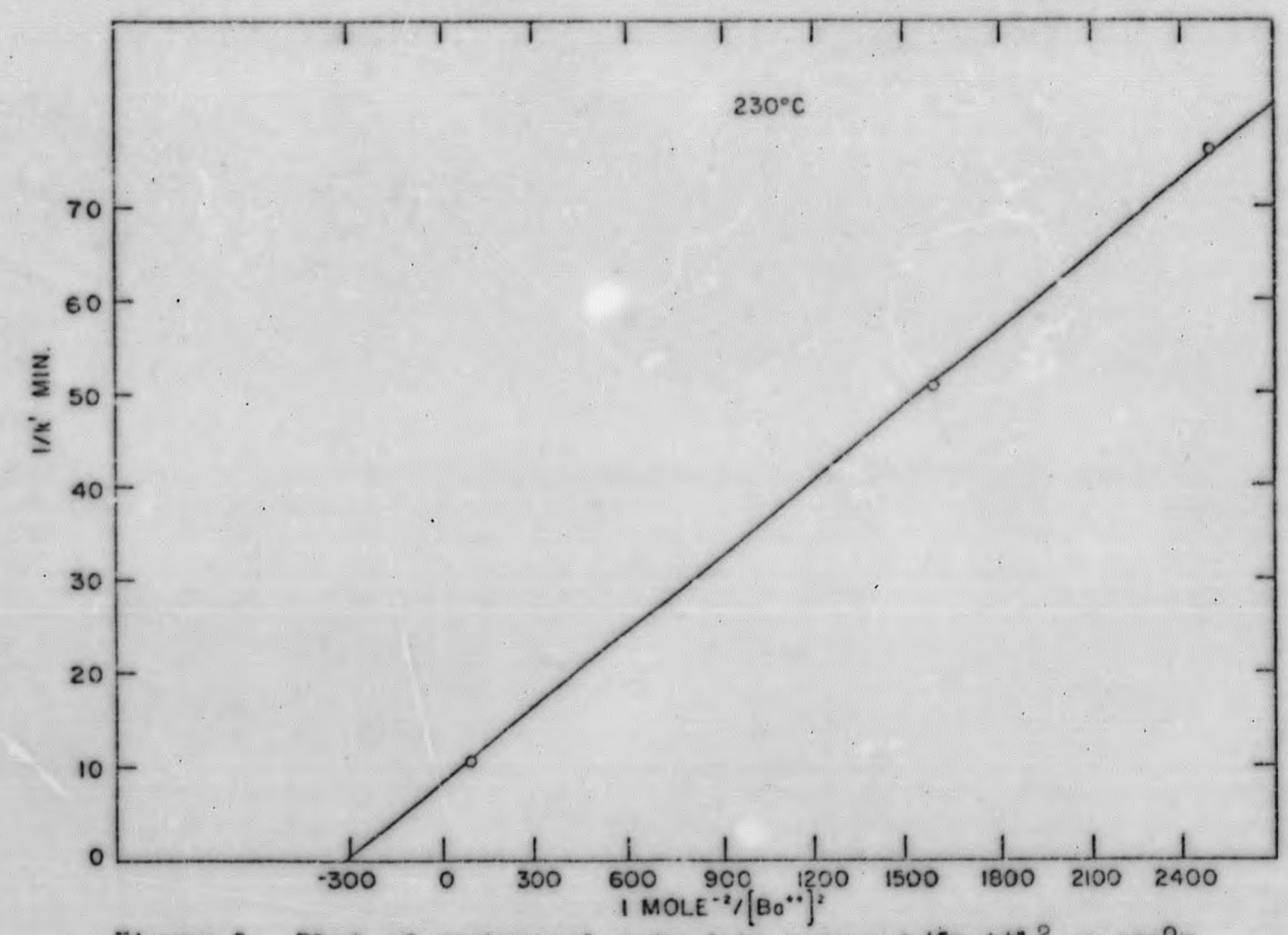

Figure 5. Plot of reciprocal rete data versus $1 /\left[\mathrm{Ba}^{++}\right]^{2}$ at $230^{\circ} \mathrm{C}$ 
Teble 2. Variation of the pseudo rete constant with barlum 100 et $230^{\circ} \mathrm{C}, 250^{\circ} \mathrm{C}, 260^{\circ} \mathrm{C}$

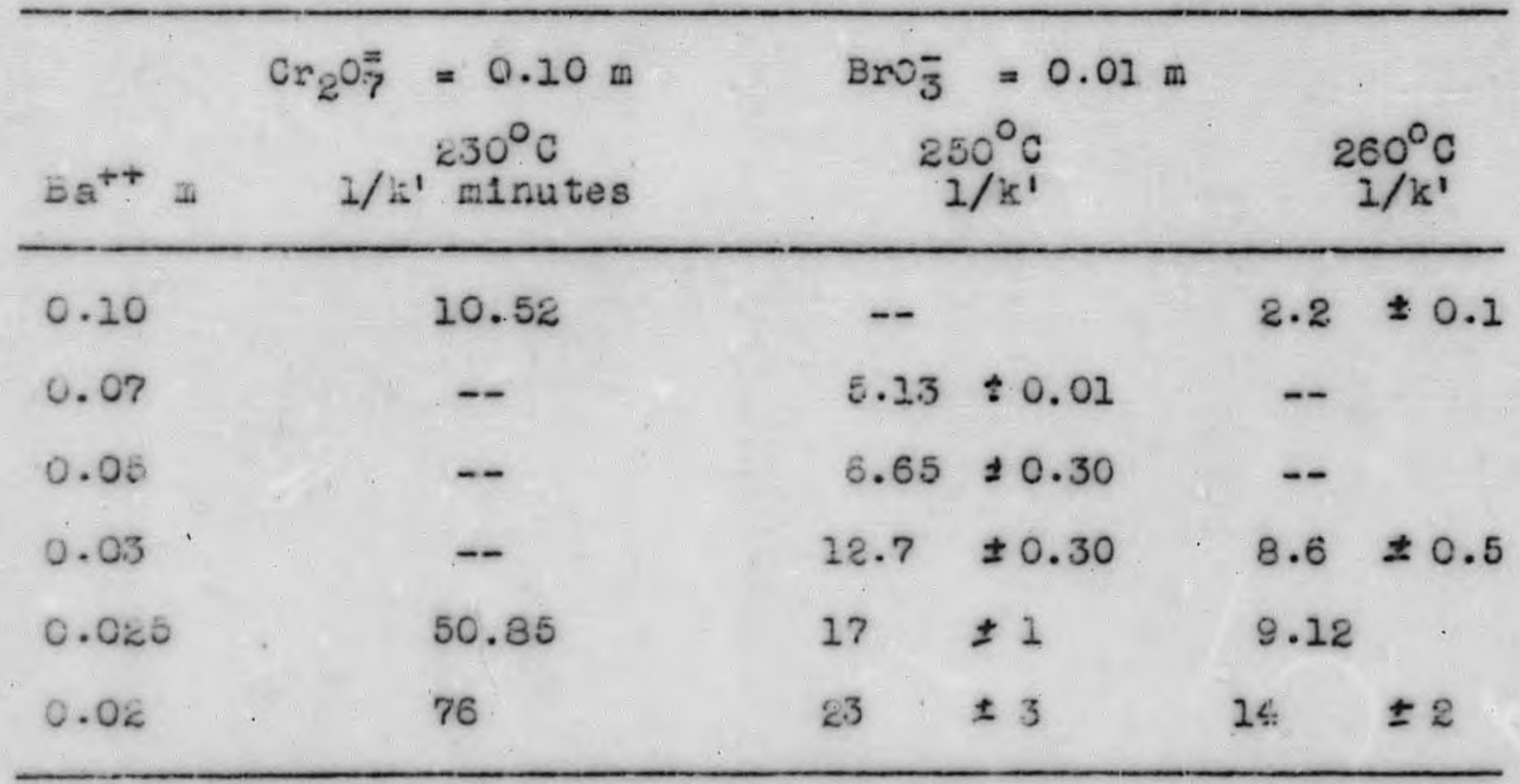

in a chegter of hls book on unusuel valence states. $\mathrm{BrO}_{2}^{+}$has been proposed as an intermediate in the mechanisms of several resctions. It 18 most often found in the reactions of 1 norganic oxyanions catalyzed by hycrogen lors and is called the electron acceptor. The order of these resctious varied from three to five. "The trend $1:$ the interpretation of rate laws greater than two hes been to formulate the mechanlsms of these resctions as a series of. uni-b1- an ter-molecular steps." (16). Thus, the mechanist proposed for the oxidetion of lodide by iromate (17) 1s,

$$
\begin{array}{ll}
\mathrm{H}^{+}+\mathrm{BrO}_{3}^{-} \rightleftharpoons \mathrm{HBrO}_{3} & \text { rast } \\
\mathrm{HBrO}_{3}+\mathrm{H}^{+} \rightleftharpoons \mathrm{H}_{2} \mathrm{BrO}_{3}^{+} & \text {rast }
\end{array}
$$




$$
\begin{array}{lll}
\text { (15) } & \mathrm{I}^{-}+\mathrm{H}_{2} \mathrm{BrO}_{3}^{+} \rightarrow \mathrm{IBrO}_{2}+\mathrm{H}_{2} \mathrm{O} & \text { slow } \\
\text { (16) } & \mathrm{IBrO}_{2} \rightarrow \text { Produets } & \text { fest }
\end{array}
$$

and Involves the "super-acla" Ion $\mathrm{H}_{2} \mathrm{BrO}_{3}^{+}$or the anhydrous form $\mathrm{BrO}_{\mathrm{C}}^{+}$. This species is stable in an acia solution of browale, and lodide is reeded to reduse bromyl to brontne, a product of this reaction. It is interesting to find that in fused nitrates an oxide acceptor in the presence of bromate w111 produce the anhydrous form of this "super-acia" 1on which decomoses unimolecularly to bromine at this high temperature.

Table 3. Rate constants and equilibrium constents for dichromate-bromate reaction - nitrogen flow rate 0.2111 ters per minute

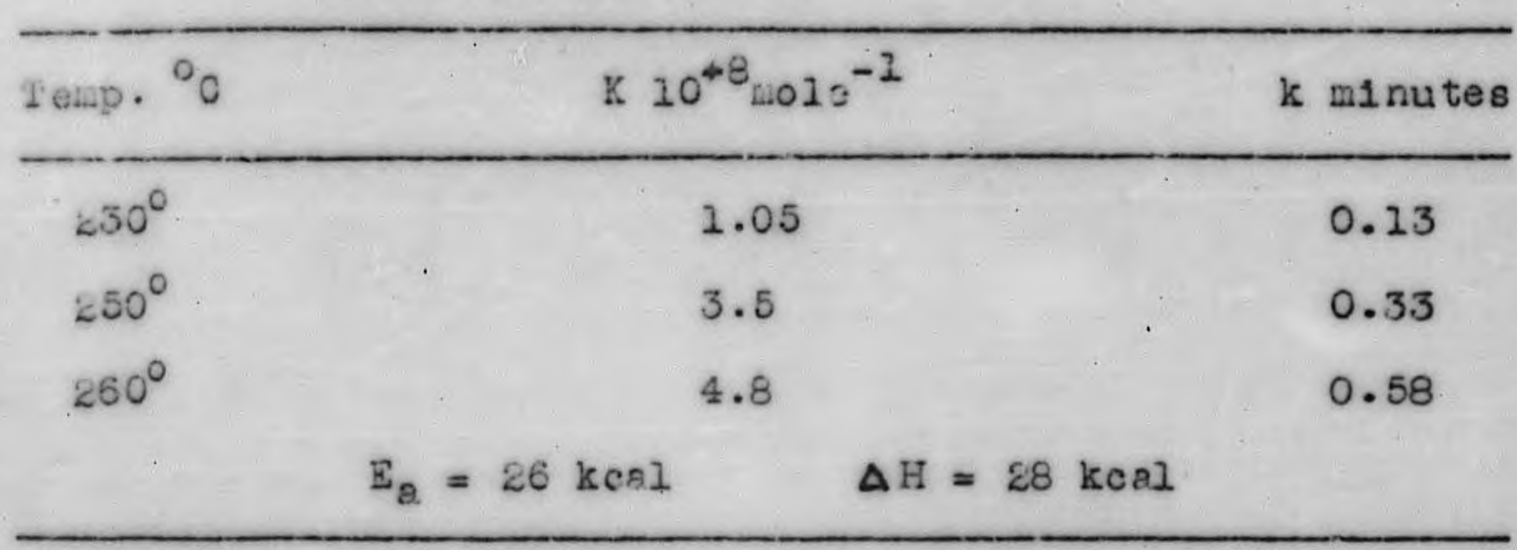

\section{z. Temperature depenôence}

The reaction was studied at two other temperatures to determine the temperature dependence of both constants ('igures 4 anâ 5). Not much separetion of the intercepts was ottalned at these temperatures. The $11 \mathrm{mlts}$ of the temperature 
ronge sre restricted becouse the repotion is too fost to follow ebove $260^{\circ} \mathrm{C}$ and the eutectic $=1 x$ ture of sodiuk end potassius nitrate freezes below $230^{\circ} \mathrm{C}$. From these data the eotivotion energy end hert of rection esn be celculeted. Whe setivation enerey for the decompostion of bromyl ion wrs obtelned from. the slope of the Arrhenlus plot shown in Fletere 6.

Therwodynasie quentities such es entropy of sotivetion, tree buargy of aotivation, snd ete. esn be colculsted frock boltzese's constent, PIsnek's constert, the rete conetent end the corresponaliag tempersture. The reletionshlo,

$$
\mathrm{k}=\frac{\mathrm{k}_{\mathrm{B}^{2}}}{\mathrm{n}} \mathrm{x}
$$

Used for these calculotions is deflned by Frost and Pesrson (18). However, the more recent cuaton $1 \mathrm{~s}$ to $11 \mathrm{st}$ the sotivition exergy snd the pre-exponentist cerm, A, defined by the Arrhenius equation,

$$
\mathrm{k}=A \mathrm{e}^{-\Sigma_{8} / R I}
$$

The only direct inforwetion one cen obteln from the activeiton enerey is the tempersture cependence of the rote constent. The pre-exponential term, A, glves e qualitative pleture of the Eegnituce of the entropy of setivation. A lerge velue of A lnalcates a large positive entropy and small value 1ndicetes a negative entropy. Several theorles of reaction Alreties have been proposed and in most sases only one or two reactions fit the theory quantitet1vely. However the 





theoretical values and experimental values of A have been compred for many reactions and crguments have been proposed to explain the âviations. The theoreticas value of A predicted by coll'sion thecry for reactions cerried out in uqueous solutions is $10^{11}$. Thls value 18 considered to be the norm (18). Tabja 4 11sts ooloulated experimental values of A for the reactions studied in fuaed salts. The pre-exponential tern caloulated from Duke and Yamamoto's (9) data is extremely low. This 18 due to the small

Table 4. Pre-exponentiel terms celculated from activation energles and rate constents reported by the euthors ol ted

\begin{tabular}{lllll}
\hline Reference & $\mathrm{E}_{\mathrm{e}}$ cel. & $\mathrm{K}$ & $\mathrm{T}^{\mathrm{o}} \mathrm{K}$ & $\mathrm{A}$ \\
\hline Schlegel $^{a}$ & 26,000 & $0.23 \mathrm{mln}^{-1}$ & 503 & $10^{10.5}$ \\
Schlegel $^{a}$ & 26,000 & $2.95 \mathrm{~m}^{-1} \mathrm{~mole}^{-1}$ & 503 & $10^{11}$ \\
Shute (14) & 43,000 & $0.022 \mathrm{~m}^{-1} \mathrm{n}^{-1} \mathrm{~mole}^{-1}$ & 543 & $10^{12.4}$ \\
Yeuemo to (9) & 12,000 & $0.038 \mathrm{~m}^{-1} \mathrm{~mole}^{-1}$ & 508 & $10^{3.8}$ \\
\hline
\end{tabular}

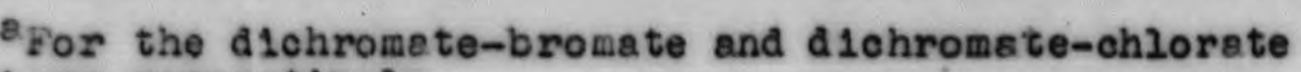
resctions respeotively.

activation energy. A small activation energy is related to a small temperature dependence of the rate of reaction. If the rate measurek 18 the rate of alfrusion of gaseous $\mathrm{N}_{2} \mathrm{O}_{5}$ to the surface of the melt, this rate of alffusion would have 
a very small temperature dependence and would give sise to

a small activation energy. The other values 110 close to the nowm stated above. The activation energy for the dichromatebromete reaction was calculeted to be $26 \mathrm{kcaj}$. The heat of reaction for the decompostion of dichromate was determined Irom,

$$
\frac{d(\operatorname{lnK})}{d(1 / T)}=-\frac{\Delta H}{R} \text {. }
$$

The value for $\Delta H$ was found to be $28 \mathrm{koal}$.

\section{Solvent effects}

The mole ratio of the cations was varied to see if there were any solvent effects on the resction rate. The esivent erfect has been measured in several resctions carried out in a.kel1 $\mathrm{m}$ trstes. In most cases on effect has been observed. Shute (14) found that a change in the cation ratio or sodiumpotassium nitrate solvent changed the rate of oxidation of bromice by bromate. Other observations included are:

(1) The reaction is autocetelytic end first order w1 th respect to both bromste and bromide.

(2) The reaction products are bromide and oxygen in sodium-potassium n1trate m1xtures; but ere tromine gas and 11 thlum oxide in lithlum nitrate.

The rete of this reaction increased as the concentration of soalum 1on was 1ncreased. Shute (14) attributed th1s observation to a larger polarizing power of the sodium ion on 
bromate. The polarialng effect facliltates the opproach of the two negative 1ons; bromate and brom1de, to forti the aot1vated complex. Therefore the postuleted meohanlem 16 ,

$$
\begin{array}{rrr}
(20) & \mathrm{K}^{+}+\mathrm{BrO}_{3}^{-} \rightarrow \mathrm{M}^{+} \mathrm{BrO}_{3}^{-} \\
(21) & \mathrm{M}^{+} \mathrm{BrO}_{3}^{-}+\mathrm{Br}^{-} \rightarrow \mathrm{M}^{+} \mathrm{BrO}_{3}^{-} \mathrm{Br}^{-} \\
(22) & \mathrm{K}^{+} \mathrm{BrO}_{3}^{-} \mathrm{Br}^{-} \rightarrow \mathrm{K}^{+}+\mathrm{BrO}_{2}^{+} \\
(23) & \mathrm{BrO}_{2}^{-} \rightarrow \mathrm{Products}^{+} \\
(24) & 2 \mathrm{BrO}^{-} \rightarrow \mathrm{Br}^{-}+\mathrm{BrO}_{8}^{-} \\
& \text {or } \mathrm{BBrO}^{-} \rightarrow \mathrm{Br}^{-}+2 \mathrm{BrO}_{3}^{-}
\end{array}
$$$$
\text { (22) } \quad \mathrm{K}^{+} \mathrm{BrO}_{3}^{-} \mathrm{Br}^{-} \rightarrow \mathrm{x}^{+}+\mathrm{BrO}_{2}^{+}+\mathrm{BrO}^{-}
$$$$
\text { (24) } 2 \mathrm{BrO}^{-} \rightarrow \mathrm{Br}^{-}+\mathrm{BrO}_{8}^{-}
$$

Sable 5. Effects due to cation retio of sodium and potassium nitrate at $250^{\circ} \mathrm{C}$

\begin{tabular}{llcc}
\hline $\mathrm{K} / \mathrm{Na}$ & $\mathrm{I}$ & $\mathrm{K} \times 10^{-8} \mathrm{mole^{-1 }}$ & $1 / \mathrm{k}$ m1 nutes \\
\hline $60 / 40$ & 330 & 3.2 & 3.4 \\
$50 / 50$ & 352 & 3.5 & 3.0 \\
$38 / 62$ & 520 & 4.8 & 2.7 \\
\hline
\end{tabular}

Doth the equilibrlum constart and rate constant for the alchronate-bromate reaction is increased as the solvent becomes richer in soalum ion. The increase in the equilibrium constant could be explained by postulating thet the oxide 1on transfer from bromate to elchromate proceeds $\mathbf{v}$ la the solvent cations, or that the more polarizing solvent cation polarizes the bromate 10 and thus reduces the apparent charge seen by 


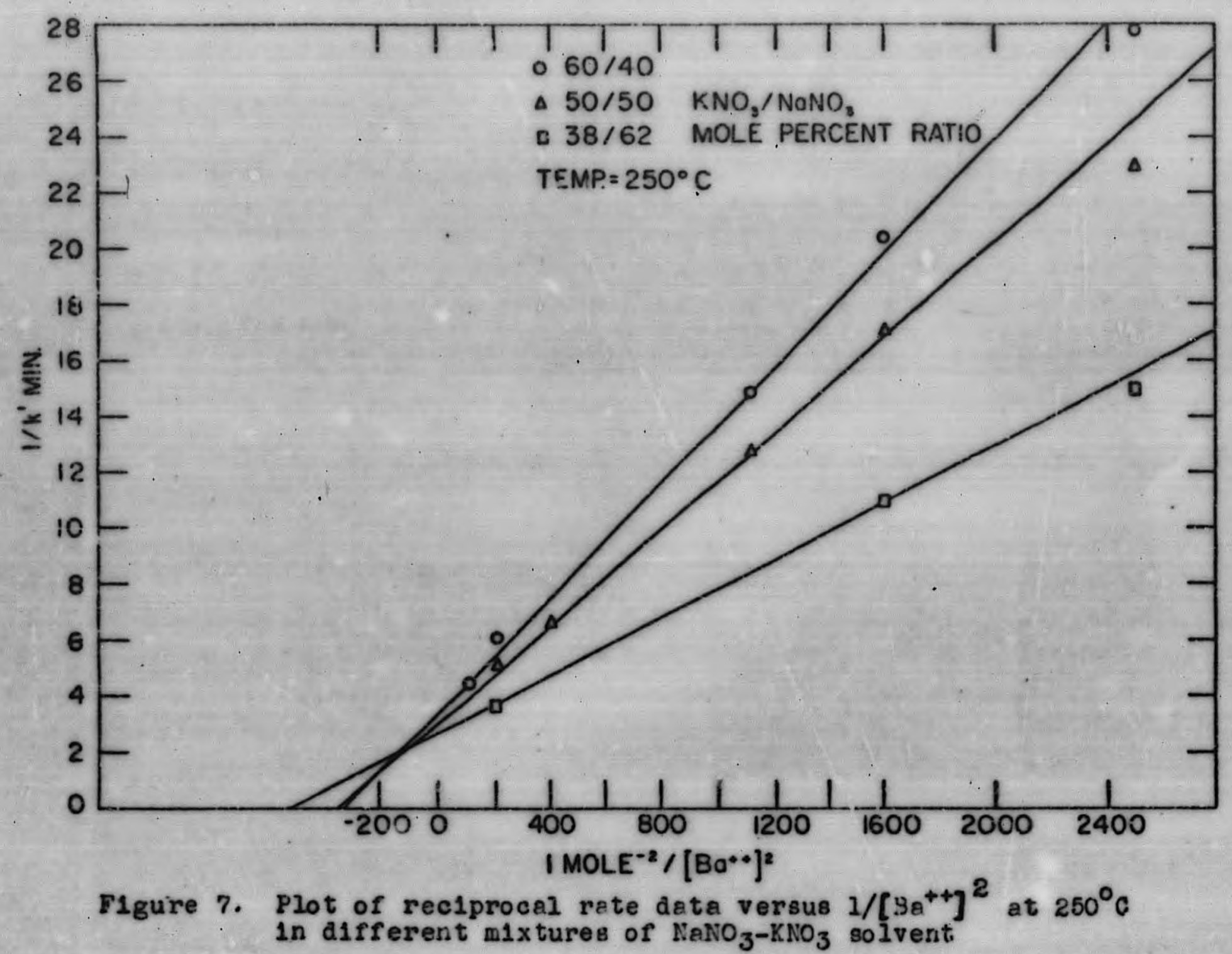


the dichromate lon shifting the equilibrium to the right. Polarlalng the bromyl ion to favor 1 ts decomposition could explain. the 1ncrease in the rate constant. It 18 interestIng to note that Lawrence (13) observed no change in the rate upon using alfferent mixtures of the alkall nitrates. It is afficult to offer any reasonable explanations for these effects. In all cases, if an effect were observed, this effect was to enhance the reactivity of the lons participating in the reaction as the concentration of the smaller alkall cations was increased.

B. The Chlorate Reaction

\section{The reaction and mechan1 sm}

Results of the reaction between bromate and dichromate hes shown the presence of bromyl ion as on. Intermediate which then decomposes to bromine and oxygen. It was thought that perhaps chlorete ara also loäte might behave in a simllar manner. If they are stroiger bases than nitrate, one could follow their behavior with dichromate in fused nitrates.

Preliminary studies w1 chlorste showed that no observable reaction occurs unless the concentration of chlorate is quite large, $2 . \mathrm{Cm}$ to $5.0 \mathrm{~m}$. Therefore runs were conâucted using fifty grams of potassium nitrate and fifty grems of sodium chlorate. This mixture is close to 50-50 mo te percent sodium-potassium, and the concentration of 


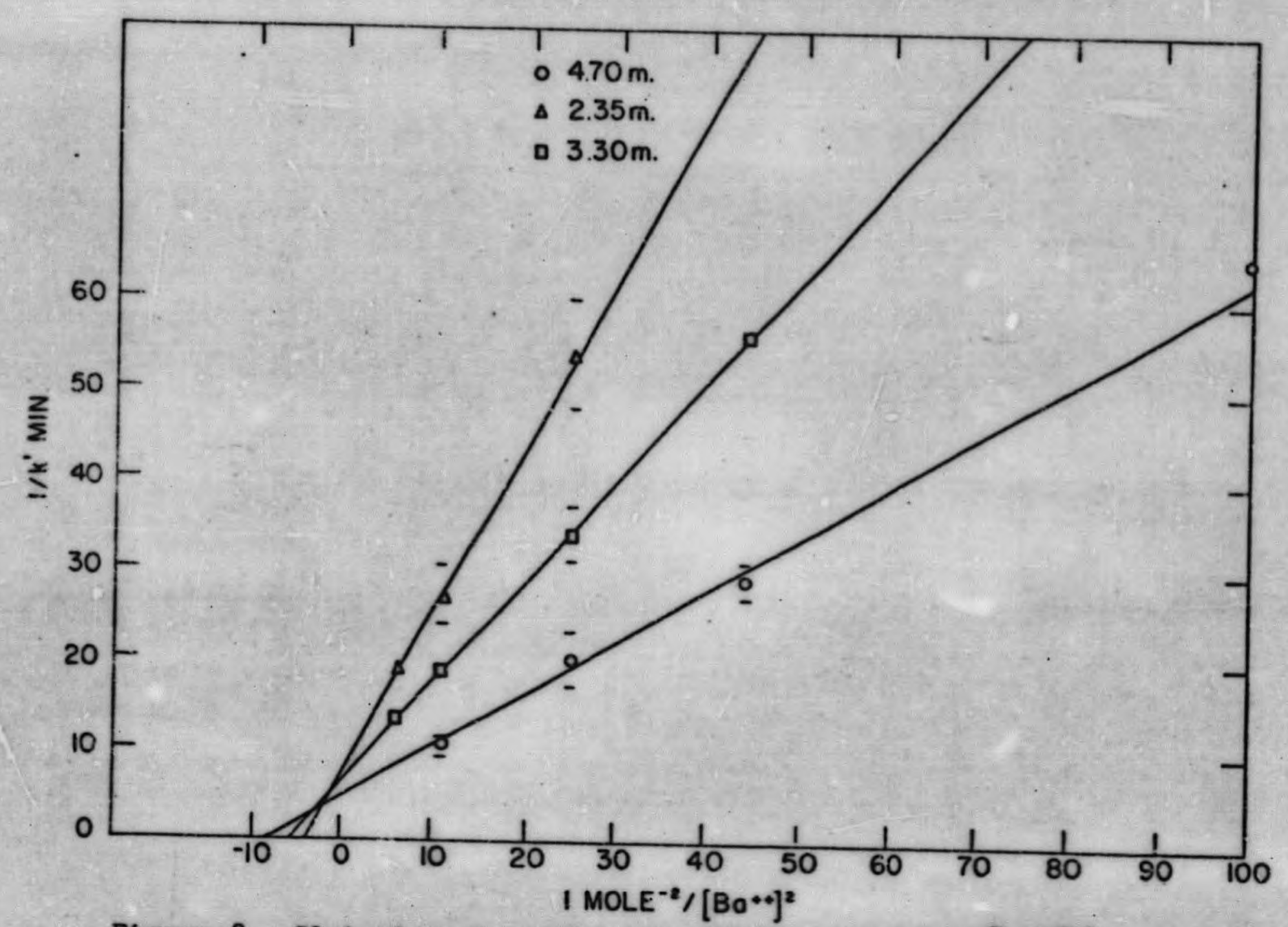

Figure 8. Plot of reciprocal rate constant versus $1 /\left[\mathrm{Ba}^{++}\right]^{2}$ st several constants therefore should be multiplied by 2,3 sellog paper and 
chlorete is almost $5.0 \mathrm{~m}$. When the concentration of chlorate was lowered, an appropriate smount of sodium nitrate was edded to keep the wole retio of sodium and potassium 50-50. The adaltion of dichromate causes en 1mmediate preclpitate of barlum chromate followed by the evolution of ohlorine or oxides of chlorine. The halogen gas was reduced w1th $0.33 \mathrm{M}$ sodium sulfite. Chloride was determined using the technique described in Section III B. It was found that no chloride was lost by the evaporation $\mathrm{or} H \mathrm{HCl}$ while the samples steemed on a hot plate. The eamples were neutralized and titrated with silver nitrate. The end point is not very clear, however a blank was run and all samples were titrated to the same end point. W1th practice, reproduclble results were obtalned using th1s method. Dlahromate is the only reactant whose concentration can be $11 \mathrm{~m} 1$ ted and followed with time. Dichromate was aded and the resction was allowed to go to completion. The reaction is complete when the precipitate is a very lemon yellow and there $1 \mathrm{~s}$ no odor of halogen gases.

In ell prellminary runs, two gram equivelent welghts of chlorine were recovered for every gram equivalent welght of dichromate. Therefore the alsappearance of alchromate on be calculated by following the appearance of chlorine. At this time 1t was as sumed that the rete determining step was,

$$
\mathrm{ClO}_{3}^{-}+\mathrm{ClO}_{2}^{+} \longrightarrow \text { Producte }
$$

because of the observed stolchlometry. The rate would be, 
(26)

$$
\mathrm{R}=\frac{\mathrm{KK}\left[\mathrm{C} 10_{3}^{-}\right]\left[\mathrm{Be}^{++}\right]^{2}}{\mathrm{~K}\left[\mathrm{C} 10_{3}^{-}\right]\left[\mathrm{Ba}^{++}\right]^{2}+\mathrm{K}_{\mathrm{sp}}^{2}} \mathrm{~T}_{\mathrm{A}}
$$

where (2B), $\mathrm{I}_{\mathrm{A}}=\mathrm{Cr}_{2} \mathrm{O}_{7}+\mathrm{ClO}_{2}^{+}$. The reaction was flrst order in dichromate aster a rather long induction period. This indiction period was 1 gnored because reproducible results were obtalned within a reasonable experimental error. Also, $1 / \mathrm{k}^{\prime}$ plotted agalnst $1 /\left[\mathrm{Ba}^{++}\right]^{2}$ gave a good stralgit ine. The data are recorded in Table 6 and a graph1 cal representation 18 presented in Figure 8. Different concentrations of shlorate were used and the results gave an order less than one in chlorete instead of an expected second

Table 6. Variation of the pseudo r1rat order rate constant with barlum ion at alfferent chlorate conoentrations (temperature is $250^{\circ} \mathrm{C}$ )

\begin{tabular}{|c|c|c|c|c|c|}
\hline $\mathrm{ClO}_{3}^{-}$ & $\mathrm{Ba}^{+4}$ & $\begin{array}{l}1 / \mathrm{x}^{\prime} \\
\text { min. mole }\end{array}$ & $\mathrm{ClO}_{3}^{-}$ & $\mathrm{Ba}^{++}$ & $\begin{array}{c}1 / k^{\prime a} \\
\text { m1n. mole }\end{array}$ \\
\hline \multirow[t]{4}{*}{$4.70 \mathrm{~m}$} & $0.30 \mathrm{~m}$ & $10.5 \pm 1.3$ & $2.35 \mathrm{~m}$ & $0.40 \mathrm{~m}$ & 19 \\
\hline & 0.20 & $20 \pm 3$ & & $0.30 \mathrm{~m}$ & $27 \pm 4$ \\
\hline & 0.15 & $29 \pm 2$ & & 0.20 & $54 \pm 6$ \\
\hline & 0.10 & 65 & & 0.15 & 88 \\
\hline \multirow{4}{*}{$3.3 \mathrm{um}$} & 0.40 & 13.4 & $1.41 \mathrm{~m}$ & 0.40 & 43 \\
\hline & 0.30 & 19 & & 0.30 & $63 \pm 3$ \\
\hline & 0.20 & $34 \pm 3$ & & 0.20 & $96 \pm 8$ \\
\hline & 0.15 & $56 \pm 1$ & & & \\
\hline
\end{tabular}


Less excess chloriâe 1s produced. See Table 7.

(4) A small amount of Initial ohloride decreases the Induetion period to negliglble amount. See Figure 9.

(5) A low order in ohloride at low conoentrations of Inltial ohloride is observed. See Figure 9.

(6) A positive test for perohlorate is observed using . methylene blue as an indicator (12).

Observations (1) and (5) Indicate the alsproportionation of chlorate to perchlorate and chloride. The disproportionation 1s possibly induced by the chloryl 1on. Th1s sort of decomposition has been observed by Harvey (19), Bosch and Aten (20), and Glasner and Weldenreld (21), when they studied the thermal decomposition of perchlorate and chlorate. Observations (1) and (3) Indicate that chloride 18 needed for the chlorate-dichromate reaction to proceed. The rate determining s tep becomes,

$$
\mathrm{ClO}_{2}^{+}+\mathrm{Cl}^{-} \rightarrow \text { Products }
$$

at hlgh concentrations of chloride. A plot of $\log \mathrm{Cl}^{-}$versus $\log \mathrm{k}^{2}$ gives a slope of 0.77 at hlgh coneentrations of chlor1de. If the chloride concentration found in the melt at the end of the reaction is used in this plot, the slope 18 true for all chloride concentrations. The polnt at which the curve deviates Irom a stralght line is where the Initial chloride equals $0.08 \mathrm{~m}$. Th1s concentration $1 \mathrm{~s}$ not far from 
Tablo 7. Chloride concentration at different concentrations of reactents and the observed rate constants

\begin{tabular}{|c|c|c|c|c|c|c|c|}
\hline $\mathrm{CLO}_{3}^{-}$ & $\begin{array}{l}B \mathrm{a}^{++} \\
\mathrm{II}\end{array}$ & $\mathrm{Cr}_{2} \mathrm{O}^{\mathrm{m}}$ & $\mathrm{Cl}^{-}$InItial. & $\mathrm{Cl}^{-}$finel & $\mathrm{Cl}^{-}$excess & $\begin{array}{c}1 / k^{\prime} \\
m 1 n \cdot m o l e\end{array}$ & $m_{1} n^{-k_{m o l e}^{\prime}}$ \\
\hline $\begin{array}{l}4.70 \\
4.70 \\
4.70 \\
4.70 \\
4.70\end{array}$ & $\begin{array}{l}0.20 \\
0.20 \\
0.20 \\
0.20 \\
0.20\end{array}$ & $\begin{array}{l}0.01 \\
0.01 \\
0.01 \\
0.02 \\
0.015\end{array}$ & $\begin{array}{l}0.04 \\
0.08 \\
0.0 \% \\
0.00 \\
0.00\end{array}$ & $\begin{array}{l}0.082 \\
0.108 \\
0.077 \\
0.087 \\
0.078\end{array}$ & $\begin{array}{l}0.042 \\
0.028 \\
0.051 \\
0.087 \\
0.078\end{array}$ & $\begin{array}{l}17.4 \\
14.0 \\
18.5 \\
20.0 \\
18.0\end{array}$ & $\begin{array}{l}0.0575 \\
0.0714 \\
0.0540 \\
0.0500 \\
0.0555\end{array}$ \\
\hline $\begin{array}{l}4.70 \\
4.70 \\
4.70 \\
4.70 \\
4.70\end{array}$ & $\begin{array}{l}0.20 \\
0.20 \\
0.20 \\
0.20 \\
0.20\end{array}$ & $\begin{array}{l}0.01 \\
0.01 \\
0.01 \\
0.01 \\
0.01\end{array}$ & $\begin{array}{l}0.00 \\
0.30 \\
0.20 \\
0.15 \\
0.082\end{array}$ & $\begin{array}{l}0.065 \\
0.298 \\
0.202 \\
0.16 \\
0.111\end{array}$ & $\begin{array}{l}0.065 \\
0.002 \\
0.060 \\
0.01 \\
0.029\end{array}$ & $\begin{array}{r}20.0 \\
6.0 \\
8.3 \\
8.5 \\
12.5\end{array}$ & $\begin{array}{l}0.0500 \\
0.1667 \\
0.1205 \\
0.1177 \\
0.0800\end{array}$ \\
\hline $\begin{array}{l}4.70 \\
4.70 \\
4.70 \\
4.70 \\
4.70\end{array}$ & $\begin{array}{l}0.20 \\
0.20 \\
0.20 \\
0.10 \\
0.15\end{array}$ & $\begin{array}{l}0.01 \\
0.01 \\
0.01 \\
0.01 \\
0.01\end{array}$ & $\begin{array}{l}0.08 \\
0.05 \\
0.10 \\
0.30 \\
0.30\end{array}$ & $\begin{array}{c}0.108 \\
0.086 \\
= \\
= \\
=\end{array}$ & $\begin{array}{c}0.028 \\
0.036 \\
=- \\
=\end{array}$ & $\begin{array}{r}14.0 \\
15.0 \\
13.0 \\
18.2 \\
8.3\end{array}$ & $\begin{array}{l}0.0714 \\
0.0667 \\
0.0770 \\
0.0550 \\
0.1205\end{array}$ \\
\hline $\begin{array}{l}4.70 \\
4.70 \\
1.414 \\
4.70 \\
4.70\end{array}$ & $\begin{array}{l}0.12 \\
0.30 \\
0.20 \\
0.30 \\
0.15\end{array}$ & $\begin{array}{l}0.01 \\
0.01 \\
0.01 \\
0.01 \\
0.01\end{array}$ & $\begin{array}{l}0.30 \\
0.30 \\
0.00 \\
0.00 \\
0.00\end{array}$ & $\begin{array}{l}-- \\
0.039 \\
0.061 \\
0.068\end{array}$ & $\begin{array}{l}-. \\
0.039 \\
0.061 \\
0.068\end{array}$ & $\begin{array}{c}12.0 \\
3.7 \\
- \\
=- \\
-\end{array}$ & $\begin{array}{l}0.0833 \\
0.2700 \\
- \\
- \\
-\end{array}$ \\
\hline 4.70 & 0.20 & 0.01 & 0.40 & 0.40 & 0.000 & 4.6 & 0.2170 \\
\hline
\end{tabular}




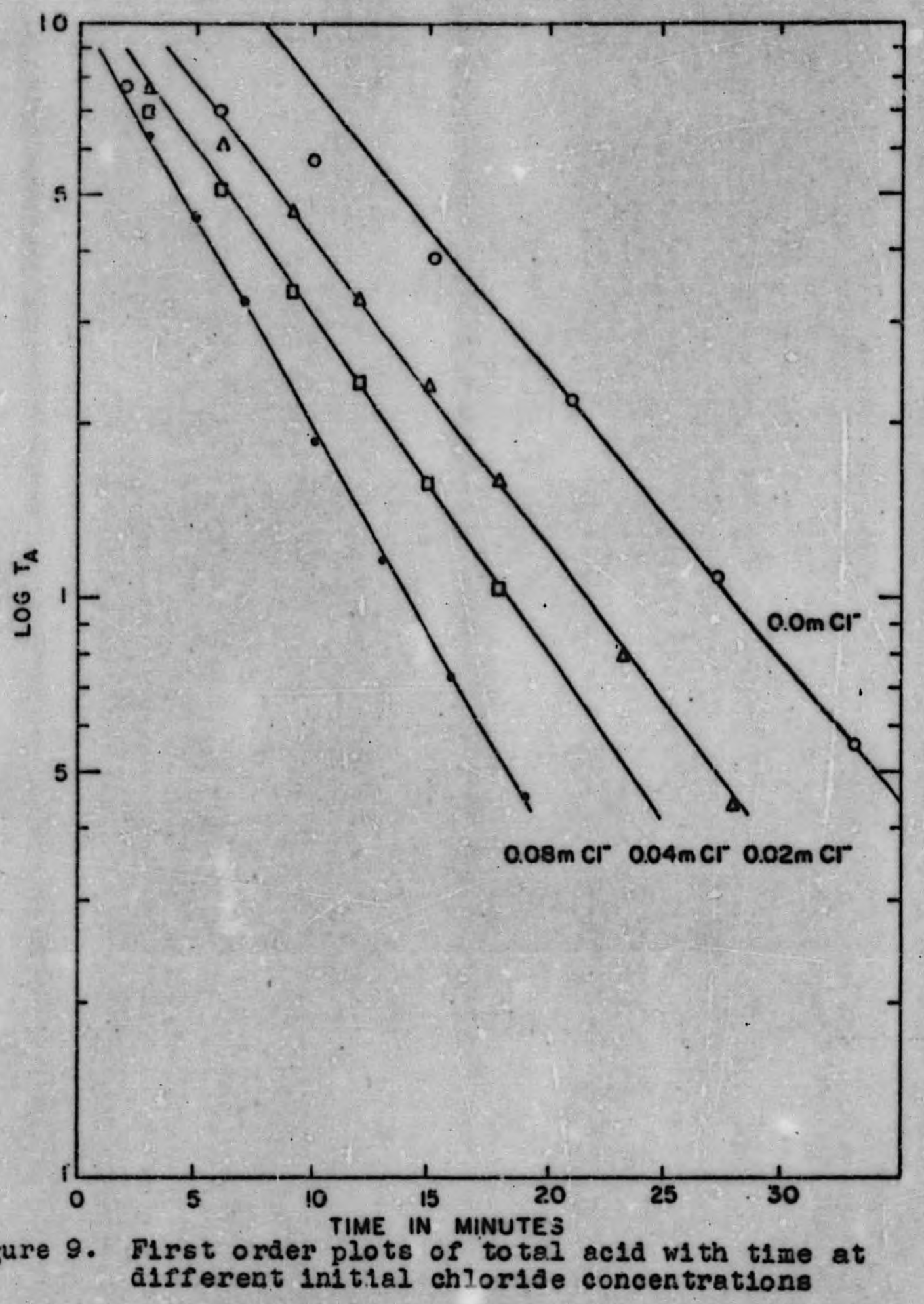




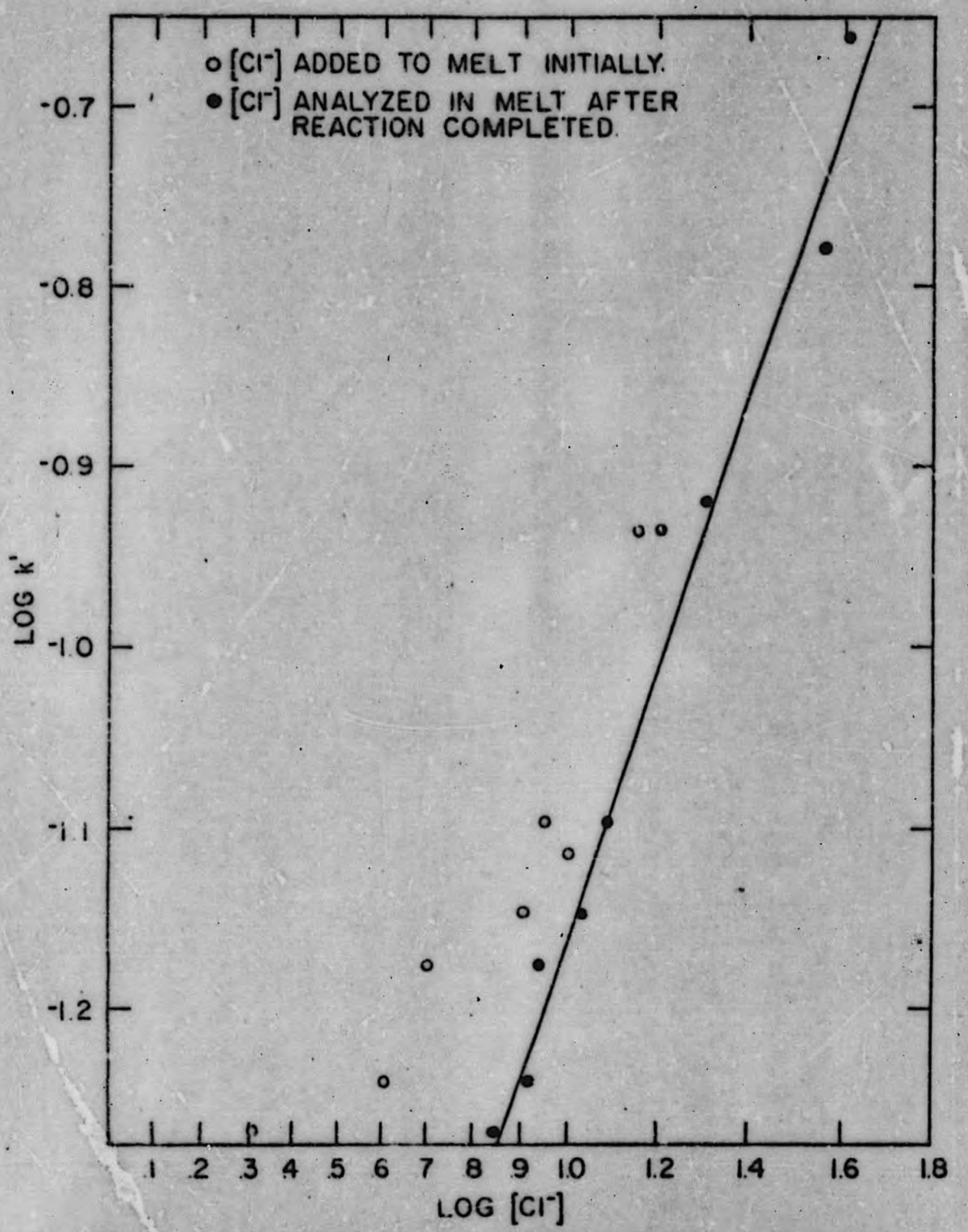

Figure 10. Plot to determine order to chloride; both initial chloride and chloride anaiyzed in the solution are plotted; rate constants obtained from ser: $1-\log$ plots and should be multiplied by 2.3 
the concentration of chlorice found in the melt at the end of a reaction which contalned no inltial chloride. Th1s observation would partialiy justify the extrapolation procedure used to evaluate the pseudo rate.constant when a long Inoduction period was present.

\section{A new mechan1sm}

Chloriae remains constant throughout a run when the Inltial chlorice concentration $1 \mathrm{~s} 0.30 \mathrm{~m}$. Therefore pseudo rate constants were obtasned at three baxium concentrations with $0.30 \mathrm{~m}$ initial chloride. The results are plotted in F1gure 11. The absoissa intercept is the same as that obtained earlier when no inltial chloride was added. It appears that the equilibrium constant is unaffected by the aswount of chlorlde present in the melt. A mechanlsm would then be,

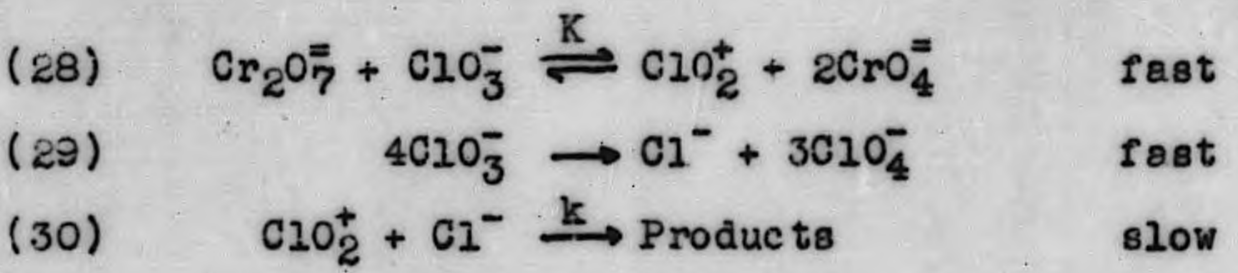

Equation 29 is just a way of representing the production of chloride from chlorate. There is a suspleion that ohloryl Ion promotes the decomposition of chiorate to chloride. However the decomposition of chlorate to chloride takes place quite fast compared to reaction 30 anå consequently, reaction 29 does not appear in the rate expression at h1gh concentrations of chloride. Thus, 


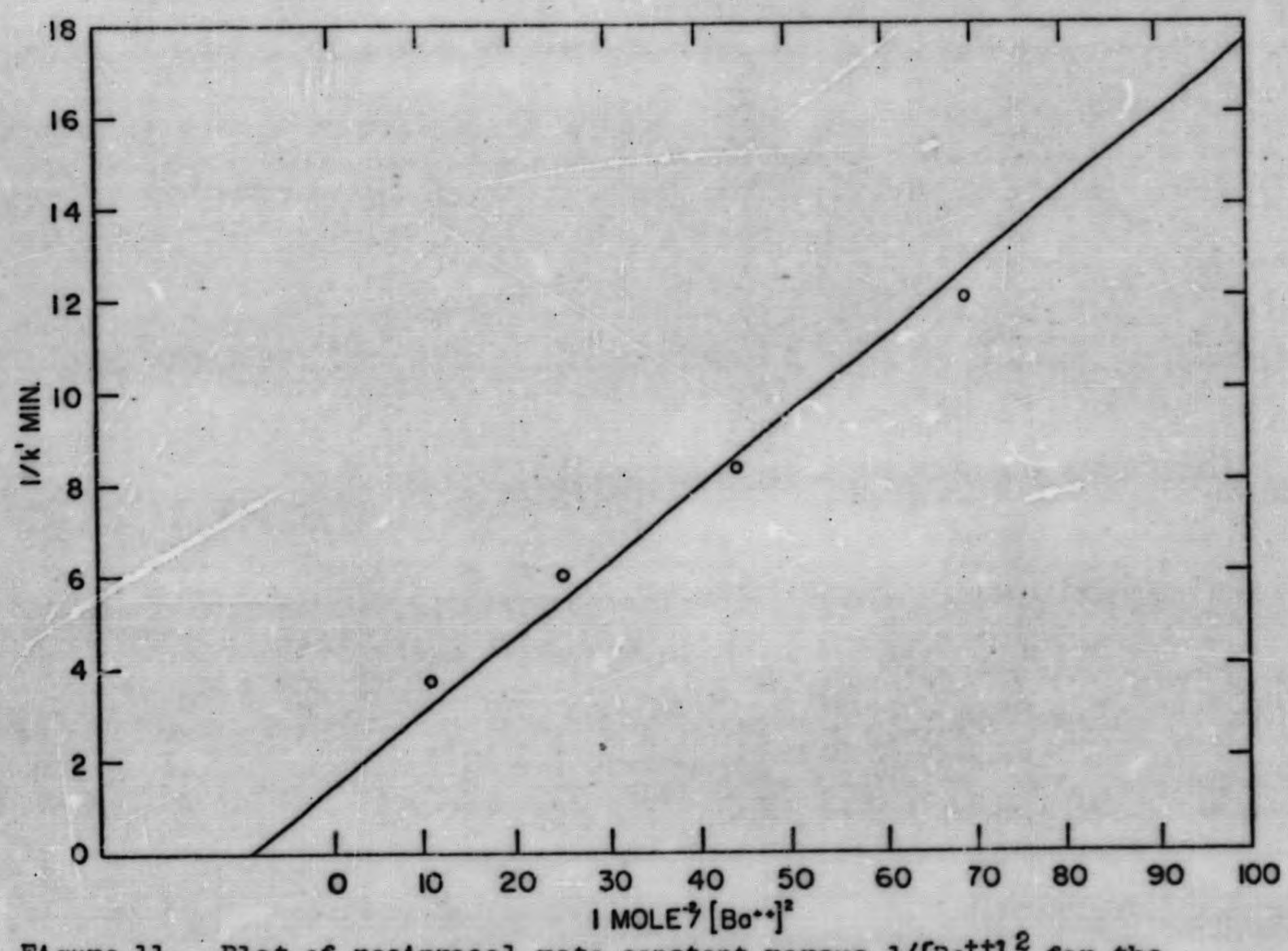

F1gure 11. Plot of reolprocal rate constant versus $1 /\left[\mathrm{Ba}^{++}\right]^{2}$ for the dichromate-chiorate reaction when $0.30 \mathrm{~m}$ inftial chloride $1 \mathrm{~s}$ ured 
(32)

$$
\text { Rate }=k\left[\mathrm{C}_{2} \mathrm{O}_{2}^{+}\right]\left[\mathrm{Cl}^{-}{ }^{-}\right]=-\frac{\mathrm{dT}_{\mathrm{A}}}{\mathrm{dt}}
$$

where,

(32)

$$
\mathrm{T}_{\mathrm{A}}=\mathrm{Cr}_{\varepsilon} \mathrm{O}_{7}^{\mathrm{a}}+\mathrm{ClO}_{2}^{+} \text {. }
$$

Frow the equilibrium expression and the solubillty product of barium chromete,

$$
\left[\mathrm{Cr}_{2} \mathrm{O}_{7}^{\Rightarrow}\right]=\frac{\mathrm{K}_{\mathrm{sD}}^{2}}{\mathrm{~K}\left[\mathrm{C} 1 \mathrm{O}_{3}^{-}\right]\left[\mathrm{Ba}^{++1}\right]^{2}+\mathrm{x}_{\mathrm{sp}}^{2}}{ }^{\mathrm{T}} \text {. }
$$

Differentiate with time,

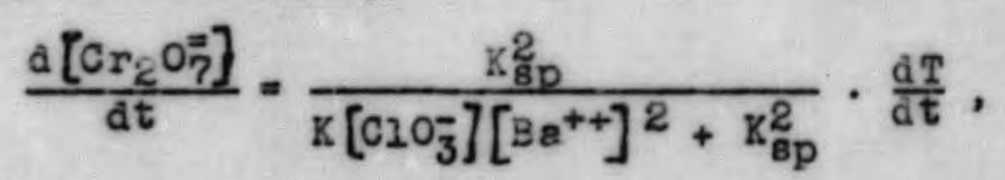

and substitute (31) Into this expression to oiteln,

$$
\frac{\mathrm{a}\left[\mathrm{Cr}_{2} \mathrm{O}_{7}^{\mathrm{z}}\right]}{\mathrm{at}}=-\mathrm{k}\left[\mathrm{ClO}_{2}^{+}\right]\left[\mathrm{Cl}^{-}\right] \frac{\mathrm{x}_{\mathrm{ep}}^{2}}{\mathrm{x}\left[\mathrm{C}_{3} \mathrm{O}_{3}^{-}\right]\left[\mathrm{Ba}^{++}\right]^{2}+\mathrm{x}_{\mathrm{sp}}^{2}} .
$$

Subst1 tute for [C $\left.10_{2}^{+}\right]$,

$$
\frac{\mathrm{d}\left[\mathrm{Cr}_{2} \mathrm{O}_{7}^{\circ}\right]}{\mathrm{dt}}=\frac{\mathrm{kK}\left[\mathrm{ClO}_{3}^{-}\right]\left[\mathrm{Cl}^{-}\right]\left[\mathrm{Ba}^{++}\right]^{2}}{\mathrm{k}\left[\mathrm{ClO}_{3}^{-}\right]\left[\mathrm{Ba}^{++}\right]^{2}+\mathrm{k}_{\mathrm{sp}}^{2}}\left[\mathrm{Cr}_{2} \mathrm{O}_{7}^{=}\right]=\mathrm{k}^{\prime}\left[\mathrm{Cr}_{2} \mathrm{O}_{7}^{-}\right] \text {. }
$$

The reclprocal of $\mathrm{k}^{\prime} 1 \mathrm{~s}$,

$$
\frac{1}{\mathrm{~K}^{1}}=\frac{1}{\mathrm{k}\left[\mathrm{Cl} 1^{-}\right]}+\frac{\mathrm{k}_{\mathrm{BD}}^{2}}{\mathrm{kK}\left[\mathrm{ClO}_{3}^{-}\right]\left[\mathrm{Cl}^{-}\right]} \cdot \frac{1}{\left[\mathrm{Ba}^{++}\right]^{2}} .
$$

If one sets $1 / k^{\prime}$ equel to zero, the equilibrium constant 18 related to the absolssa intercept, I, by,

$$
\mathrm{x}=\frac{\mathrm{x}_{\mathrm{sp}}^{2} \mathrm{I}}{\left[\mathrm{C}_{3} \mathrm{O}_{3}^{-7}\right.} \text {. }
$$


It was found that the production of chloriae, that 1s, the chloride found in the melt at the end of a run, is nearly 1ndependent of the barium concentration. The relationship (35) shows that the intercept is alrecily proportional to the concentration of ohlorate,

$$
\frac{\mathrm{K}}{\left[\mathrm{ClO}_{3}^{-}\right]}=\frac{\mathrm{K}}{\mathrm{K}_{8 \mathrm{p}}^{2}}=\text { constant }
$$

Th1s was observed 1n F1gure 8 . The value obtained for the equilibrium constant was $8 \times 10^{-11}$ mole $e^{-1}$. The orainate 1 tercept is related to the rate constant and the chloride concentration. Analysis of the melt shows that the chloride concentration produced 18 not in direct proportion to the amount of chlorete present. When the chlorate concentration was decreased by more than one-third, the chloride found in the melt was only decreased by one-sixth. Th1s information in acialtion to equation 34 woula explain the small chenge in the ordinate intercept in Flgure 8 . The low order in chloride at 8 all concentrations of Initial chloriae suggests that there is some decomposition taiklng place which is 1ndependent of chloride, or, $k^{\prime}=k_{1}^{\prime}+k_{2}^{\prime}\left[\mathrm{Cl}^{-}\right]$. To oheok th1s, $k^{\prime}$ was plotted against $\left[\mathrm{Cl}^{-}\right]$, Flgure 12. A stralght line can be arrewn through these points and $\mathrm{k}_{1}=.046$ and $\mathrm{k}_{2}=1.15$. The predominant rate step is the one involving chloride. However at low inltial chloride the other rate step would be noticeable. 


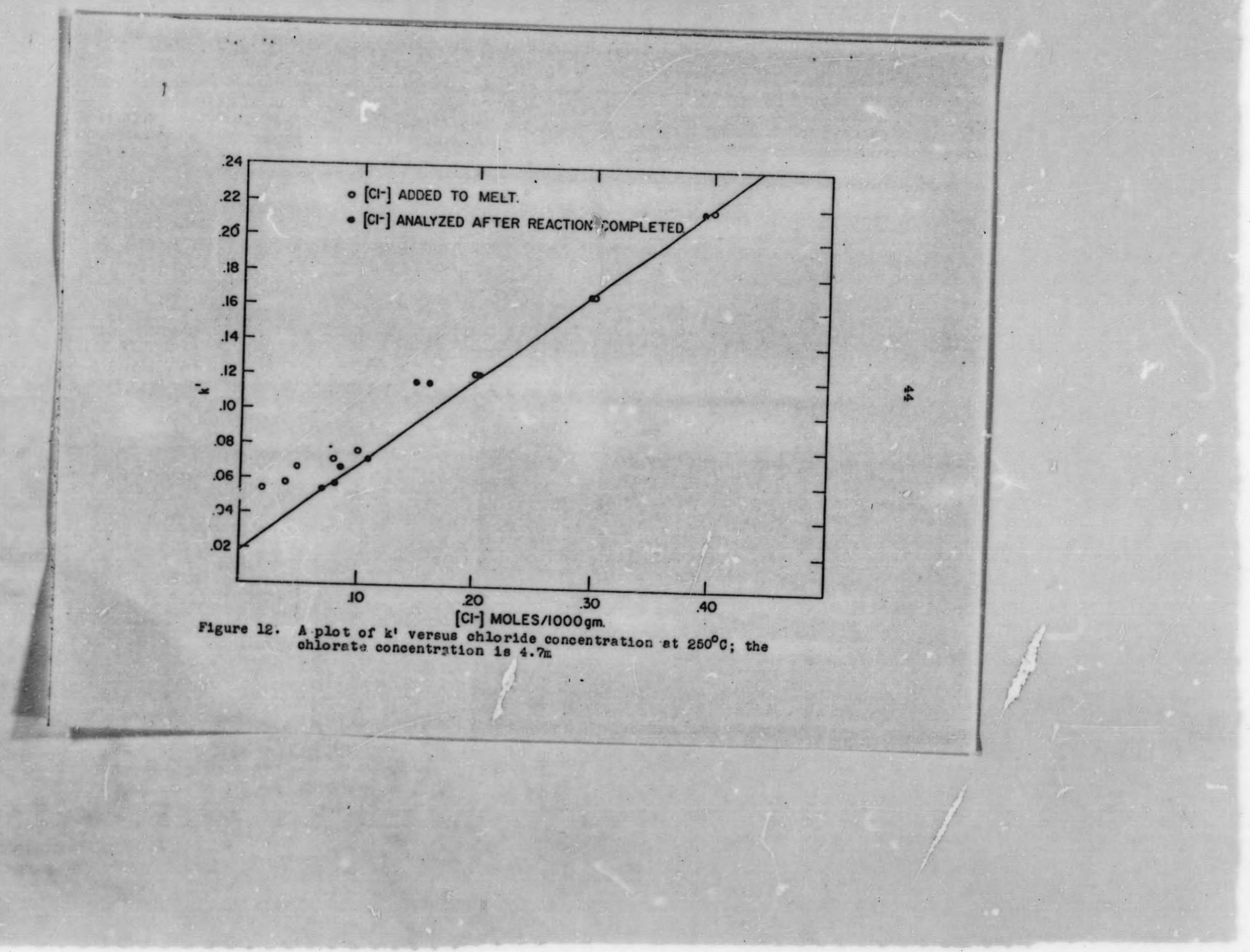


The mechan $1 \mathrm{sm}$ of the alchromate-chlorate reaction has been establlshed well enough to determine the constant of the flret equiliorium lnvolving the formation of ohloryl ion. Subsequent steps whlch Plnally lead to barlum chromate, chlorlde, chlorine, and oxygen are not so well understood. However the data Indicste the predominant slow step to be,

$$
\mathrm{ClO}_{2}^{+}+\mathrm{CJ}^{-} \rightarrow \text { Products }
$$

In aqueovis solution studies of the ohlorate-chloride reaction, the nucleus of 211 the rate laws is the complex $\mathrm{Cl}_{2} \mathrm{O}_{2}$, whose concentration 18 given by the expression,

$$
\left.\left[\mathrm{Cl}_{2} \mathrm{O}_{2}\right]=\mathrm{x}\left[\mathrm{CLO}_{3}^{-}\right]\left[\mathrm{Cl}^{-}\right] \mathrm{HH}^{+}\right]^{2}
$$

A alscrepancy in the order of reactents is found when the stuales of Sand (22), H1rede (23), and Luther and KacDougall $(24,25)$ are compared. Sand (22) and H1rade (23) observed the rate law,

$$
\mathrm{R}=\mathrm{k}\left[\mathrm{ClO}_{3}^{-}\right]\left[\mathrm{Cl}^{-}\right]\left[\mathrm{K}^{+}\right]^{2},
$$

while Luther and NacDougall (24) found,

$$
\text { (40) } \mathrm{R}=\mathrm{k}\left[\mathrm{ClO}_{3}^{-}\right]^{2}\left[\mathrm{Cl}^{-}\right]^{2}\left[\mathrm{H}^{+}\right]^{4}
$$

In the presence of lodide lon and browlde lon respectively, Brag (26) and Hirade (23) observed the equation,

$$
\mathrm{R}=\mathrm{k}\left[\mathrm{ClO}_{3}^{-}\right]\left[\mathrm{Cl}^{-}\right]\left[\mathrm{H}^{+}\right]^{2}
$$

Edwards (16) polnts out that the reaction of chlorete w1th water takes place through the equilibrium,

$$
\mathrm{ClO}_{3}^{-}+2 \mathrm{H}^{+} \rightleftharpoons \mathrm{H}_{2} \mathrm{ClO}_{3}^{+} \rightleftharpoons \mathrm{ClO}_{2}^{+}+\mathrm{H}_{2} \mathrm{O}
$$

W1th ohloride present the equilibrium expression becomes, 
(43)

$$
\mathrm{Cl}^{-}+\mathrm{ClO}_{3}^{-}+2 \mathrm{H}^{+} \rightleftharpoons \mathrm{Cl}_{2} \mathrm{O}_{2}+\mathrm{H}_{2} \mathrm{O} \text {. }
$$

It appears that the cotiplex $\mathrm{Cl}_{2} \mathrm{O}_{2}$ decomposes by coll1sion with a nuoleophllic porticle. Ihls complex oould be in equilibrium w1th $\mathrm{C} 3 . \mathrm{O}_{2}^{+}$and $\mathrm{Cl}^{-}$in fused nitretes, however the rate ehould aecresse as the chloride concentration is increased. The opposite effect in fact was observed.

\section{Temera ture äependence}

It was mentioned earlier that the dichromete-chlorate reaction was followed at a lower tempersture of $230^{\circ} \mathrm{C}$. However these aata were obtalned when no initial chloride was added. Three points, whlch gave a stralght 11ne, were obtalned at $4.70 \mathrm{~m}$ chlorate, end two points were obtalned at a lower chlorate concentration. If one assumes that a temperature change does not affect the production of chloride, these data can be usea to evaluate an approximate activation energy for the dichromate-chlorate reaction. The concentration of chloride was assumed to be $0.065 \mathrm{~m}$ at $4.70 \mathrm{~m}$ chlorete and $0.400 \mathrm{~m}$ for $1.414 \mathrm{~m}$ chlorate and the rete constants were determined from the ordinate intercept. A value of $26 \mathrm{kcal}$. was found using the data from $4.70 \mathrm{~m}$ chlorate and $31 \mathrm{kcal}$. from $1.414 \mathrm{~m}$ chlorate. Nore points were obteined for the data at $4.70 \mathrm{~m}$ chlorate, therefore the activation energy $26 \mathrm{kcal}$. Is used to calculate the pre-exponentlal term recoraded in Table 4. It was shown that the eouliabrium constant of the abscissa 
Intercept is independent of chloride. Therefore this observation was assumed to be true at $230^{\circ} \mathrm{C}$ and the heat of reaction was determined. Th1s value, $27 \mathrm{koal}$., 16 very close to the heat of reaction for the alchromate-bromate reaction.

\section{The Iodate Reaction}

\section{Preliminary stuales}

The bromate reaction has been characterized quite thoroughly. No hallde 10 is needed to catalyze thls. reaction so that 1 t may be followed. However chlorlde is necessary for the chlorate reaction to proceed at a measurable rate. In fact, it is imposstble to study the chlorate reaction in the absence of chlorica because chloride is a product of this reaction. Intuitively one would expect the chlorate ion to be the weaker base. But one would also expect the lodate Ion to be the strongest base and the reaction between lodate and dichromate to take place at a more rap1d rate.

Frellminary runs have shown that no reaction occurs at Iow concentrations of lodate. This reaction cannot be studied at very high concentrations of lodate because of 1 ts $11 \mathrm{mlted}$ solubility in fused $n t$ trates. Therefore sodium bromide was added to increase the rate of reaction using low concentrations of lodate. The following concentrations were used: $0.10 \mathrm{~m} \mathrm{Cr}_{2} \mathrm{O} \overline{7}, 0.01 \mathrm{~m} \mathrm{IO}{ }_{3}^{-}, 0.10 \mathrm{~m} \mathrm{Br}-$. At these concentrations of reactants, nitrate olsc oxidized bromide and thus inter- 
fered with the lodate reaction. Therefore the oxidation of cromiçe by nltrate and dichromate was studied in the absence of socete.

\section{The nitrate reection}

The reaction between dichromate ond a base can be represented in some cases as,

$$
\mathrm{Cr}_{2} \mathrm{O}_{7}^{=}+\mathrm{BO}_{3}^{-} \rightleftharpoons \mathrm{BO}_{2}^{+}+2 \mathrm{CrO}_{4}^{=} \text {. }
$$

If the intermediate, $\mathrm{BO}_{2}^{+}$, formed in the equilibrium, is a strong enough ac1d compared to the ac1d reactant, $\mathrm{Cr}_{2} \mathrm{O}_{7}$; a plot of $1 / \mathrm{k}^{\prime}$ versus $\mathrm{l}\left[\mathrm{Ba}^{++}\right]^{2}$ w1ll give a straight line that lies so close to the origin that it is 1npossible to evaluate on 1ntercept. Such is the gase when Duke and Iverson (27) studied the decomposition of dichromate in a fused alkall nitrate mixture. They obtained values for the product of the equilibrium constant and the rate constant but were unable to separate the two quantities. However they used lead lon as the precipltating agent which forms complexes with dicnromate and possibly bromide. This complexing phenomenon decreases the activity of the alchromate and the bromlde, and also decreases the activity of the leed lon which arives the equilibrlum. If one uses barium in place of lead and follows the appearance of bromino with time, it is possible to separate the equiliorium and rate constants.

A small amount of dichromate was used and 1 ts concentra- 
t1on was followed by observing the appearance of bromine gas. Duke arid Iverson (27) had found this reaction to be first order in bromicie. At high concentrations of barlum one grem equivalent weight of bromine was recovered for every gram equivalent welght of dichromate; thia Indicates that the rate is first order in bromide. At low concentrations of berium the rate was too slow to allow the reaction to go to completion. Therefore 1 was assumed that the inltial concentration of alchromate, $0.01 \mathrm{~m}$, was the amount aded to the melt. Barlum nltra.te was varled from $0.10 \mathrm{~m}$ to $0.30 \mathrm{~m}$. The data are Iisted in Table 8 and an appropriate plot is shown in Figure 13.

Table 8. Variation of the pseudo first order rate constant with barlum ion 1 n the dichromate-nitrate reaction at $250^{\circ} \mathrm{C}$

\begin{tabular}{cl}
$\begin{array}{c}\mathrm{Cr}_{2} \mathrm{O}^{-}=0.01 \mathrm{~m} \\
\mathrm{Ba}^{++} \mathrm{m}\end{array}$ & $\begin{array}{c}\mathrm{Br}^{-}=0.10 \mathrm{~m} \\
1 / \mathrm{s}^{\prime} \mathrm{min} \cdot \mathrm{mole}\end{array}$ \\
\hline 0.15 & 340 \\
0.17 & 292 \\
0.20 & 213 \\
0.25 & 141 \\
0.30 & 114 \\
\hline
\end{tabular}




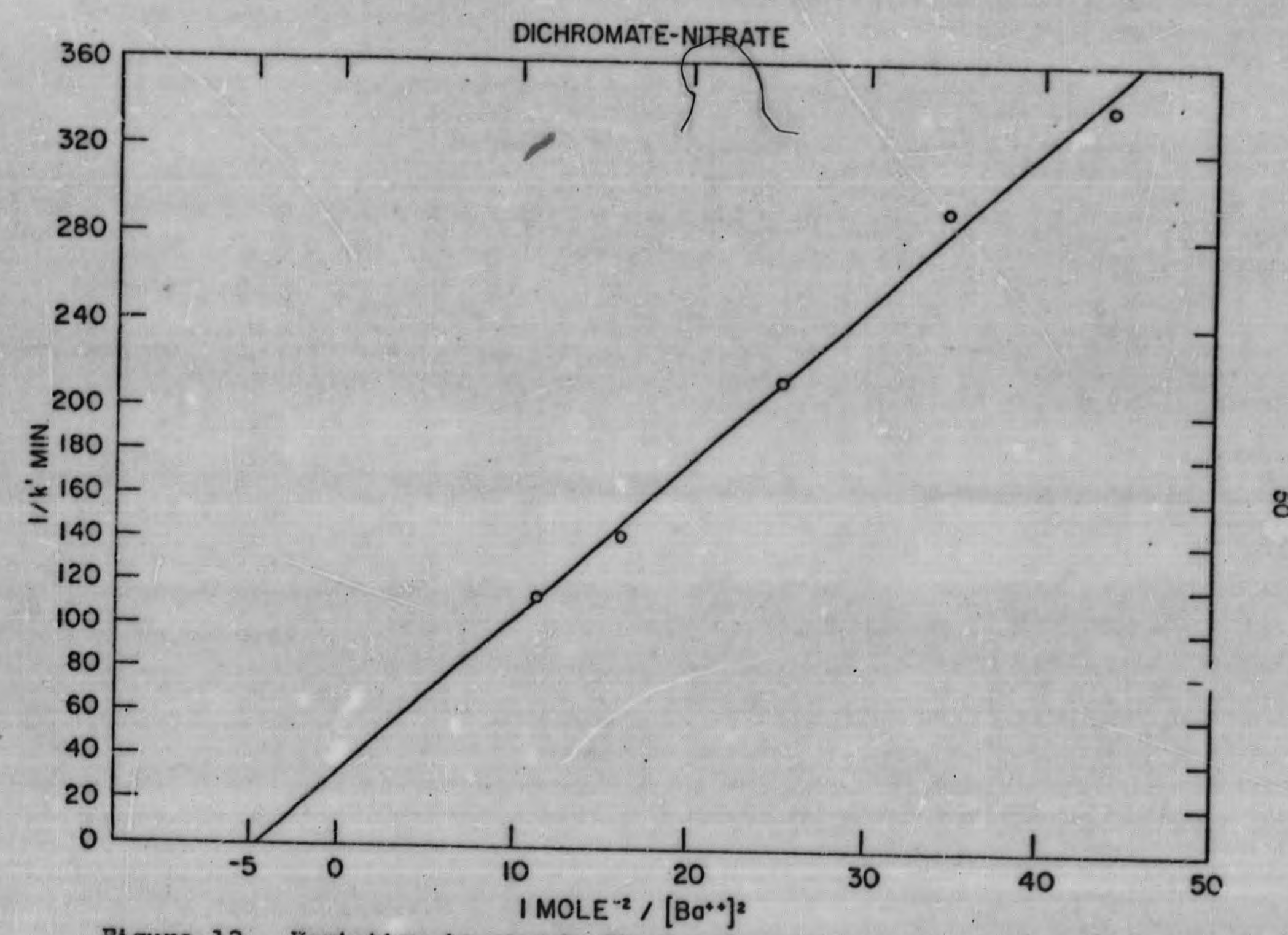

Figure 13. Varlation in pseudo first order rate constant $w i$ th barium for the dichromate-nitrate reaction 


\section{The mechen18m}

The oxidation of bromide by dichromete and nitrate proceeds at a meacurable rate if a large concentration of barium 1s aded. Th1s reaction 18 essily suppressed by keeping the concentrations or barlum and dichromate low. A very small emount of 1odate 1ncreases th1s rate consliderably. Therefore the following concentrations were used: $0.01 \mathrm{~m} \mathrm{Cr}_{2} \mathrm{O}_{7}$, $0.10 \mathrm{~m} \mathrm{IO}_{3}^{-}, 0.10 \mathrm{~m} \mathrm{Br}^{-}$. D1chromate $1 \mathrm{~s}$ the $11 \mathrm{~m} 1 \mathrm{t} 1 \mathrm{ng}$ concentration. Iolate reacts completely w1th alchromate betore any observable amount of nitrate does. These conditions make 1 t possible to follow the reaction to completion because no reaction occurs after all the dichromate has reacted. The gases formed from the reaction contain both lodine and brom1re. For every gram equivalent welght of dichromate two gram equivalent we1ghto of hologen were recovered. The reaction is flrst order in the disappearance of total acla. The concentrations of barluin and bromlde were varied and the results are 11 sted $1 \mathrm{n}$ Table 9 . The temperature was $250^{\circ} \mathrm{C}$ for 811 runs. A plot of $\log \mathrm{Br}^{-}$versus $\log \mathrm{k}^{\prime}$ is shown in F1gure 14. The slope of this ine indicetes a f1rst order dependence in bromide. The simplest mechanism to explain these observstlons would be,

$$
\begin{array}{ll}
\mathrm{Cr}_{2} \mathrm{O}_{7}+\mathrm{IO}_{3}^{-} \rightleftharpoons \mathrm{IO}_{2}^{+}+2 \mathrm{CrO}_{4}^{\prime} & \text { sast } \\
\mathrm{IO}_{2}^{+}+\mathrm{Br}^{-} \longrightarrow \text { Products } & \text { slow }
\end{array}
$$




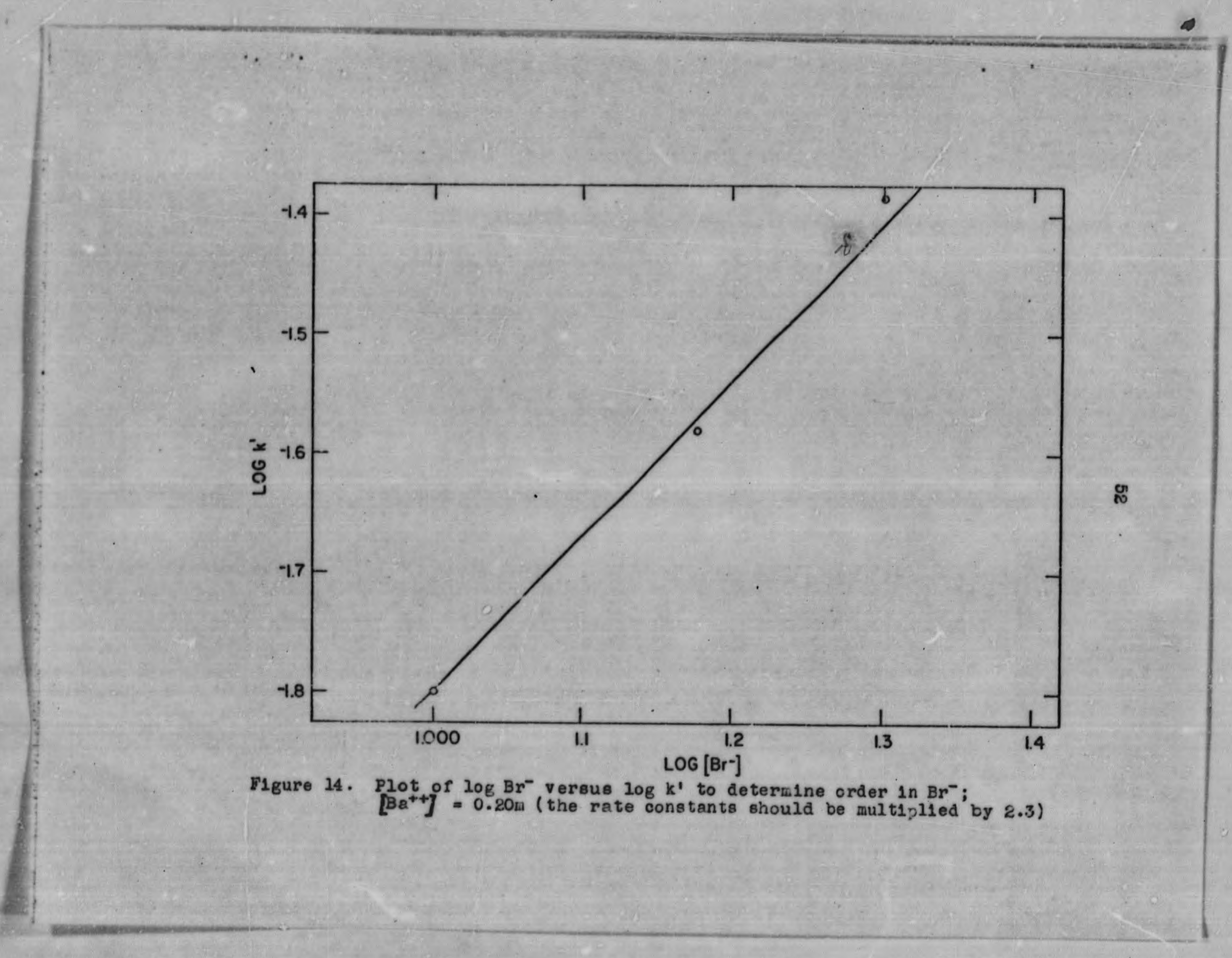


Table 9. Verlation of the pseudo flrst order rate constant w1 th. concentrations of reactants

\begin{tabular}{|c|c|c|c|c|}
\hline $\begin{array}{l}\mathrm{Ba}^{++} \\
\mathrm{m}\end{array}$ & $\mathrm{IO}_{\overline{3}}^{-}$ & $\mathrm{Cr}_{\mathrm{m}} \mathrm{O}$ & $\underset{m}{B r^{-}}$ & $\begin{array}{c}1 / k^{\prime} \\
\min \cdot \operatorname{mol}\end{array}$ \\
\hline 0.10 & 0.10 & 0.01 & 0.10 & 63 \\
\hline 0.08 & 0.10 & 0.01 & 0.10 & 90 \\
\hline 0.07 & 0.10 & 0.01 & 0.10 & 116 \\
\hline 0.10 & 0.10 & 0.01 & 0.15 & 38 \\
\hline 0.10 & 0.10 & 0.01 & 0.20 & 26 \\
\hline 0.10 & 0.20 & 0.01 & 0.10 & 70 \\
\hline 0.10 & 0.10 & $\begin{array}{l}0.02 \\
10^{-9} \mathrm{mo} \\
0 \mathrm{~min}^{-1}\end{array}$ & 0.10 & 64 \\
\hline
\end{tabular}

The rate expression,

$$
\text { Rate }=-\frac{\mathrm{dT}_{\mathrm{A}}}{\mathrm{dt}}=\frac{\mathrm{kK}\left[\mathrm{IO}_{3}^{-}\right]\left[\mathrm{Ba}^{++}\right]^{2}\left[\mathrm{Br}^{-}\right]}{\mathrm{K}\left[\mathrm{IO}_{3}^{-}\right]\left[\mathrm{Ba}^{++}\right]^{2}+\mathrm{K}_{\mathrm{Bp}}^{2}} \mathrm{~T}_{\mathrm{A}}=\mathrm{kT}_{\mathrm{A}} \text {, }
$$

where $\mathrm{T}_{\mathrm{A}}=\mathrm{Cr}_{2} \mathrm{O}_{7}+\mathrm{IO}_{2}^{+}$, 1s analogous to the other reactions that were studied. The reciprocal of the pseudo first ordar rate constant becomes,

$$
\frac{1}{\mathrm{k}^{\top}}=\frac{1}{\mathrm{k}[\mathrm{Br}-]}+\frac{\mathrm{K}_{\mathrm{sp}}^{2}}{\mathrm{kK}\left[\mathrm{Br}^{-}\right]\left[\mathrm{IO}_{3}^{-}\right]} \cdot \frac{1}{\left[\mathrm{Ba}^{++}\right]^{2}}
$$

A plot of $\mathrm{k} / \mathrm{kT}$ versus $1 /\left[\mathrm{Ba}^{++}\right]^{2}$ 1s shown in F1gure 15 .

The oxidation of lodide by lodate has been studied in aqueous solutions. The $11 \mathrm{fth}$ order rate law, 


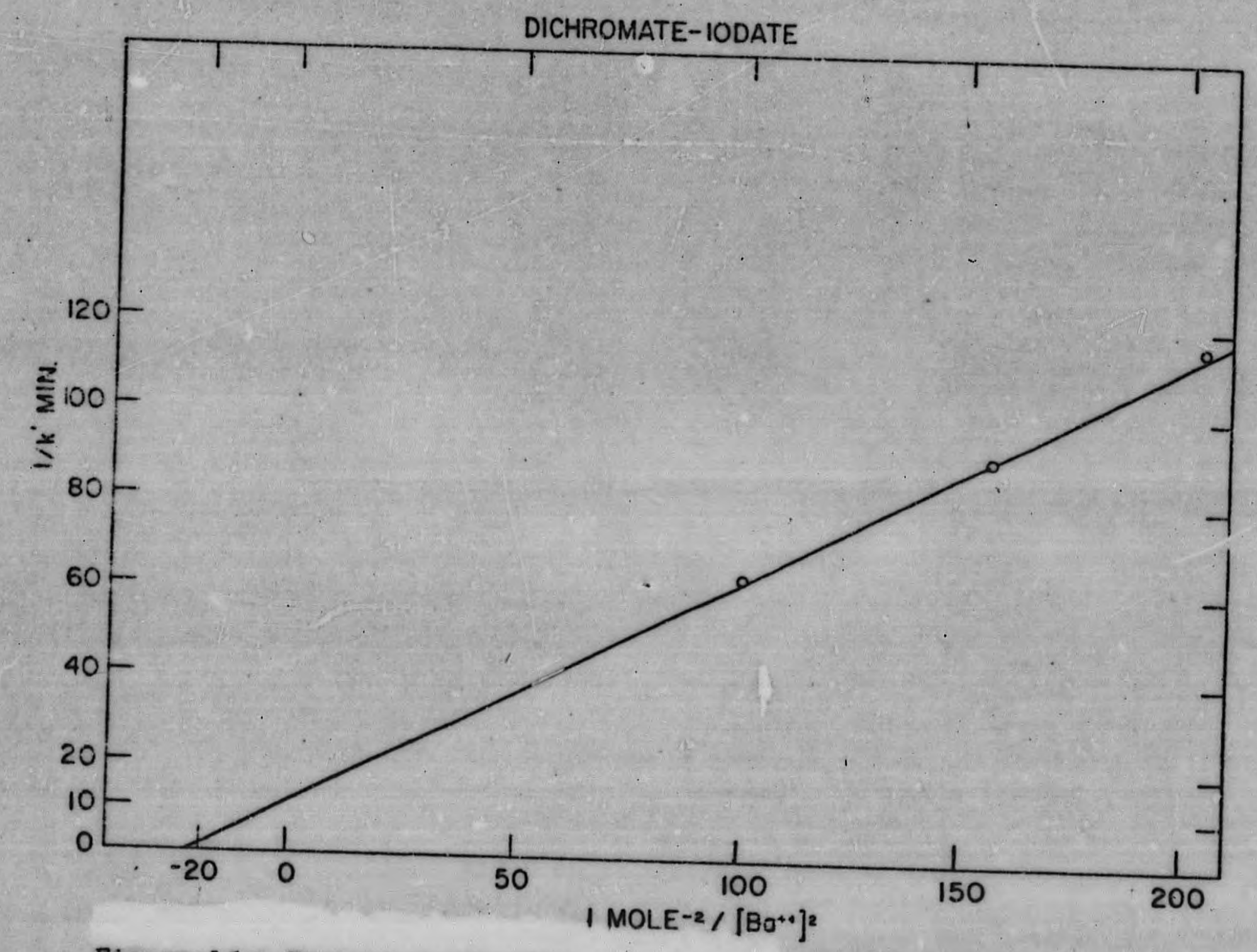

Figure 15. Variation of pseudo first order rate constant with barium should be multiplied by 2.3 ) 


$$
R=k_{3}\left[\mathrm{IO}_{3}^{-}\right]\left[\mathrm{I}^{-}\right]^{2}\left[\mathrm{H}^{+}\right]^{2}
$$

wes observed by Abel and Stadier (28), Dushman (29), and Skrebel and Zahorke (30). Abel and Hilferding (31) found a fourth-order law whlch is probebly related to the others with water as the nucleophillc perticle. Connick and Hugus (32) reperted the work of Abel and Hilferding (31) using a different procedure. In perchlorate medium of constant lonlc strength they found,

$$
\mathrm{R}=\mathrm{k}\left[\mathrm{IO}_{3}^{-}\right]\left[\mathrm{I}^{-}\right]\left[\mathrm{H}^{+}\right]^{2}
$$

An article on the lodate-1odide reoction introduces a mechen1sain Involving the intermediate $\mathrm{IO}_{2}^{+}$and a conplex (32). The postulated complex of the fourth order rate law was

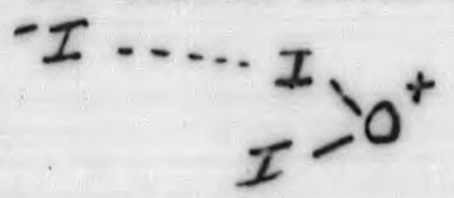

and that for the fifth order low (w1th a seconc-order dependence on lodide concentration) was s1m1lar, w1th. one lodide ion on each oxygen of $\mathrm{IO}_{2}^{+}$. 


\section{COL.CLUSIOIS AND SUMNARY}

The reactions of nitrete end ell three helates with dichromate have been studied in fused alkall nitrates. It appears thet the halates beheve slmilarly insorar as an equ1licrlum is established before decomposition occurs. However the path of aecomposition of $\mathrm{XO}_{2}^{+}$to products wes different for eech intermediete, $\mathrm{XO}_{2}^{+}$. When one represents the helate Ion in general es $\mathrm{XO}_{3}^{-}$,

$$
\mathrm{Cr}_{2} \mathrm{O}_{7}^{=}+\mathrm{XO}_{3}^{-} \rightleftharpoons \mathrm{XO}_{2}^{+}+2 \mathrm{CrO}_{4}^{=}
$$

is the gereral equilibrium expression. The equilibrium constants for the above reaction would serve as a messure or the relative aclalty of $\mathrm{XO}_{2}^{+}$. Equillorium constants were obtalned for all four aclds at $250^{\circ} \mathrm{C}$. These constents are tabulated. A probiew arises when the equilibrium constant was evelusted for nitrate and chlorate because both of these lons were incorporeted as all or part of the sulvent. In the case of nitrate, nitrate is the solvent and therefore 1 ts concentrotion coes not appesr in the equllibrium expression. In the case of chlorete, chlorate served is half of the solvent. All concentratiors are expressec as moles of reactent per 1000 Erams of solvent. Instead of reporting the chlorate concentretion es 4.7 moles per 1000 grais of solvent, and steting thet the chlorete 18 pert of the solvent, one shoujd report this \&8 4.7 moles per 500 . Erams of nitrate solvent. 
Perhaps a better way of representing the equ1librium constants of chlorate anc nitrate would be by mole frection of the halate and nitrate. The mole frection of chlorate corresponding to 4.7 moles per 1000 grams of solvent $1 \mathrm{~s} 0.488$, and the wole frection of nitrate in a sodum-potassium nitrate mixture is one. The equilibrium end rate constants for these reactione at $250^{\circ} \mathrm{C}$ are recorded in Table 10 .

Table 10. The equilibrium constants and rate congtants for 811. of the resctions stualed, $\mathrm{C}_{\mathrm{F}_{2}} \mathrm{O}$ ? $+\mathrm{XO}_{3}^{-}$ $\mathrm{XO}_{2}^{+}+\mathrm{CCrO}_{4}^{\circ}$ ( temperature is $250^{\circ} \mathrm{E}$

\begin{tabular}{|c|c|c|}
\hline $\mathrm{xO}_{2}^{+}$ & k & $\mathrm{K}$ \\
\hline $\mathrm{BrO}_{2}^{+}$ & $0.33 \mathrm{~m}_{1 \mathrm{n}^{-1}}$ & $3.5 \times 10^{-8} \mathrm{~mole} \mathrm{e}^{-1}$ \\
\hline $\mathrm{ClO}_{2}^{+}$ & $5.60 \mathrm{~m}^{-1 \mathrm{n}^{-1}} 0.01 \mathrm{e}^{-1}$ & $4.0 \times 10^{-11}$ \\
\hline $\mathrm{NO}_{\mathrm{Z}}^{+}$ & $0.312 \mathrm{~min}^{-1} \mathrm{mo1} \mathrm{e}^{-1}$ & $4.5 \times 10^{-11}$ \\
\hline $\mathrm{IO}_{\mathrm{Z}}^{+}$ & $2.00 \mathrm{~m}_{1} \mathrm{n}^{-1} \mathrm{~mol} \mathrm{e}^{-1}$ & $2.2 \times 10^{-9} \times 01 \mathrm{e}^{-1}$ \\
\hline
\end{tabular}

The equilibrium constant obtained for the dichrometenitrate reation is lower then the value, $8.5 \times 10^{-14}$, calculated by Duke and Yamamoto (9). However several assumptions were made by Duke and Yamamo to to obtain this value.

(1) The product of constents obtalned from Duke and Iverson's (11) studies which Duke and Yemamoto used to determilne the equiliorlum constant did not include the complexing of diohromete by lesd. 
(2) The rete step for the dichromete-nitrate reaction was the same as the rate step for the pyrosulfetenitrate reation.

(3) The temperature dependence was sssumed to be I1near and the rate constants were extrapolated to the desired tempersture. The rate constants for the pyrosulfate-nitrate reaction were determined at two temperatures only.

The first assumption would introduce a sizeable error, and would explain why Duke and Yemawoto's equiliorium constant is less then the value obtolned in this study.

the equiliorium constents for nitrate and chlorate are nesily the same. The explanation of the chlorate reaction celigg esrried out without interference of the nitrate reaction is that different hallde lons were used to reduce the internedisie to gases. The nitryl $10 \mathrm{n}$ does not react with chloride to any teasurable extent âring the alchromete-chlorate resction.

From the data in Table 10, one can arrange the relative aoluty of the intermediate sold lons es $\mathrm{BrO}_{2}^{+}<\mathrm{IO}_{2}^{+}<\mathrm{ClO}_{2}^{+} \approx$ $10_{2}^{+}$, going frow weakest to strongest. The stablllty of these Intermedites can or.ly be roughly compared. Bromyl decomposes uniwolecularly at a sizeable rate, therefore 1 t would be the least stable. A nucleophilic particle is needed to measure. the decomposition of the other intermediates. Iodyl and 
nitryl can be compared because the same nucleophilic 1on, cromide, 1s used to follow thelr reaction rates. The rate constants lraicate that lodyl $1 \mathrm{~s}$ less stable than nitryl. Chloryl has the lergest rate constant. However this lon cannot be compared to the others beceuse chloride is the nucleophille ion and chlorlate is much more difficult to oxldize than bromide.

The intermediate acla lons, $\mathrm{XO}_{2}^{+}$, whlch ore postulated in this thesis have also heen postulated as partlolpeting in the mechanism of oxidetion-reduction reactions conducted in equeous systess $(6,32,34)$. Duke $(35)$ proposed a hypothes1s which expleins the general pattern emerging from the studies of oxiabtion-reduetion reections carried out in aqueous systems. Stated simply, the hypothesis is this: "An oxidation reductior reaction is preceded by, or 18 simultaneous w1 th a generalized acid-base reaction." An example is the reaction between the anions bromlde and bromate, which proceeds only in ac1a solution (34),

(1) $\mathrm{H}^{+}+\mathrm{BrC}_{3}^{-} \rightleftharpoons \mathrm{BrO}_{2}^{+}+\mathrm{OH}^{-}$

(a) $\mathrm{H}^{+}+\mathrm{OH}^{-} \rightleftharpoons \mathrm{H}_{2} \mathrm{O}$

(a) $\mathrm{BrO}_{2}^{+}+\mathrm{Br}^{-} \longrightarrow \mathrm{Br}_{2} \mathrm{O}_{2}$

kany authors ofted in this thesis conicine the equilibrium eteps $\mathrm{I}$ and $\mathrm{z}$ and write $\mathrm{BrO}_{2}^{+}$in the hydrated form to exemplify the second order dependence in hyalrogen 1on. A similar equ1licrium occurs in the dichromate-nitrate reaction oarried out 
In fused nitrates. Shute (14) observed totally dirferent proaucts in lithium nitrate than if sodium-potessium nitrate solvent when she stualed the oxidation of bromide by bromate in fused nitrates. The products in lithlum nitrete solvent were 11 thium oxide and bromine. Lithium lon is very polarizIng and is the only ion that approaches a polarizing power equivalent to hyôrogen. It would be interesting to study this reaction varying the 11 thium concentration to see if a second order dependence occurs as found in the analogous reaction carried out in water and acid.

The alkall nitrates are the only solvents in whlch acld-base reactions have been studied. There are three outstanaing reasons why the alkali nitrates were chosen as a solvent.

(1) Katures of alkall nitrotes melt at a low temperature and are easily thermostated.

(2) They are quite stable thermally.

(3) The conjugate ecla of nitrate, $\mathrm{NO}_{2}^{+}$, 1 s stronger than the conjugate acid of other bases which makes it possible to study the reaction of these other bases with several acias. The reactions of nitrate with Lew1s ac1ds have been studied at high concentrations of nitrate simply because nitrate was the solvent. Chemical observations of perchlorate inalcate that 1 is conjugate acla is much stronger tian $\mathrm{NO}_{2}^{+}$. The slow 
reaction of aqueous perchlorate ion as an oxidant 18 a good example. Therefore lithlum perchlorate could be used as a solvent to study the reaction of many aclas w1 th a $11 \mathrm{mlted}$ concentration of nitrate. Also, the gaseous product, $\mathrm{N}_{2} \mathrm{O}_{5}$, forwed in the alohromste-nitrate and pyrosulfate-nitrate reactions, may not be soluble in 11 thlum perchlorate and a meaningful rate constant for the decomposition of nitryl ion coulâ ce evaiuated. 


\section{BIBLIOGRAPHY}

1. Levy, H. A., Argon, P. A., Bredig, M. A. and Danford, W. D. Ann. N. ‥ Aced. Sc1., 79, 762 (1960).

2. Gruen, D. M. and NaBeth, R. L. J. Phys. Chen., 63, 393 $(1959)$.

3. Audrieth, L. F. and Kleinberg, J. Non-aqueous solvents. John Wiley anâ Sons, Inc., New York. 1953.

4. Lux, A. Z. Elektrochen., 45, 303 (1939).

5. Flood, H.: and Forland, T. Acta Chew. Scand., 1, 592 .1957).

6. Yamaraoto, S. Acld-base equilibria in rused alkall nitrates. Unpubilshed Ph.D. Thesis. Library, Iowa Stote University of Science and Technology, Ames, Iowa. 1959.

7. Dice, F. and Lawrence, W., J. Amer. Chers. Soc., 83, 1269 (1961).

8. Iverson, K. L. and Duke, F. R., Complex metal halides in fused alkal1 nitrates. AEC Report ISC-943, Arses

Laboratory, Iowa State University, Ames, Iowa. 19.57.

9. Duke, F. and Yamamo to, S., I. Amer. Chem. Soc., 81, 6378 (1959).

10. Diehl, H. and Smith, G. $\vec{F}$. Quentitetive enalys1s. John willey and Sons, Inc., New York. 1952.

11. Duke, $y$. ard Iverson, $K$. J. Phys. Chem., 62, 417 (1958).

12. Sneil, F. D. and Snell, C. T. Colorimetric methods of aralysis. Vo1. 2. D. Van Nostrand Co., Inc., New York. 1953.

13. Lawrence, $W$. Kinetics of reactions lavolving bromate in fused alkal1 nitrates. Unpublished Ph.D. Thesis. Library, Iowa State University of Sclence and Technology, Ames, Iowa. 1959. 
14. Shute, E. Bromate decomposition in fused nitretes. Unpublished N. S. Thes1e. Librery, Iowa State University of Science snd Technology, Ames, Iowa.
1961.

15. Kle1nberg, J. Unfemilier oxidation states and the1r stabilization. University of Kansas Press, Lawrence, Kansas. 1850.

16. Edwards, J. O. Chem. Rev.s., 50, 455 (1952).

17. S1gelia, J. I. Chlm. Phys., 55, 758 (1958).

18. Frost, A. A. and Pearson, R. G. Kinetics and mechanisms. John Wiley and Sors, Inc., New York. 1961.

29. Harvey, A. E., Wassink, C. J., Rodgers, T. A. and Stern, K. H. Ann. ‥ Z. Acad. Sc1., 79, 971 (1260).

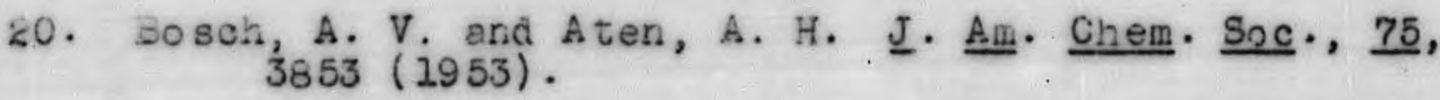

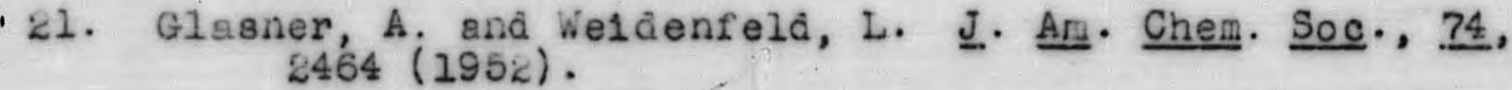

25. Sand, J. ․․ phys1k. Chem., 50, 465 (1904).

23. Hirade, J. J. Chen. Soc., Jepen, 10, 9 ? (1935).

24. Luther, R, and MecDougall, F. H. ․ Phys1k. Chem., 55, 477 (1906).

25. — and

2. Phys1k. Chem., 62, 199 (1908).

26. Bray, ซ. C. J. Phys . Chem., ?, 112 (1903).

27. Duke, F. and Iverson, M. Ankl. Chem., 31, 1233 (1959).

28. Acel, E. and Stadler, F. ‥ Phys1k. Chem., 122, 49 $(1.926)$.

29. Dushman, S. J. Phys. Chem., 8, 453 (1908).

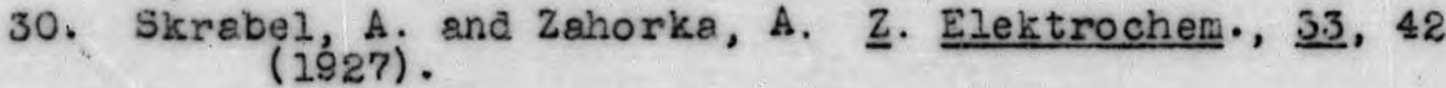

31. Abel, E. and Hilferding, K. Z. Phys1k. Chem., 136, 186 $(1923)$.

32. Connick, R. E. I. Am. Chem. Soc., 69, 1509 (1947). 
33. Norgan, K. J., Peard, K. G. and CuIlis, C. F. J. Chem. Soc., 54, 4606 (1932).

34. Clark, F. Fi. I. Phys. Chem., 11, 353 (1907).

35. Duke, F. Anal- Chem., 31, 52? (1959).

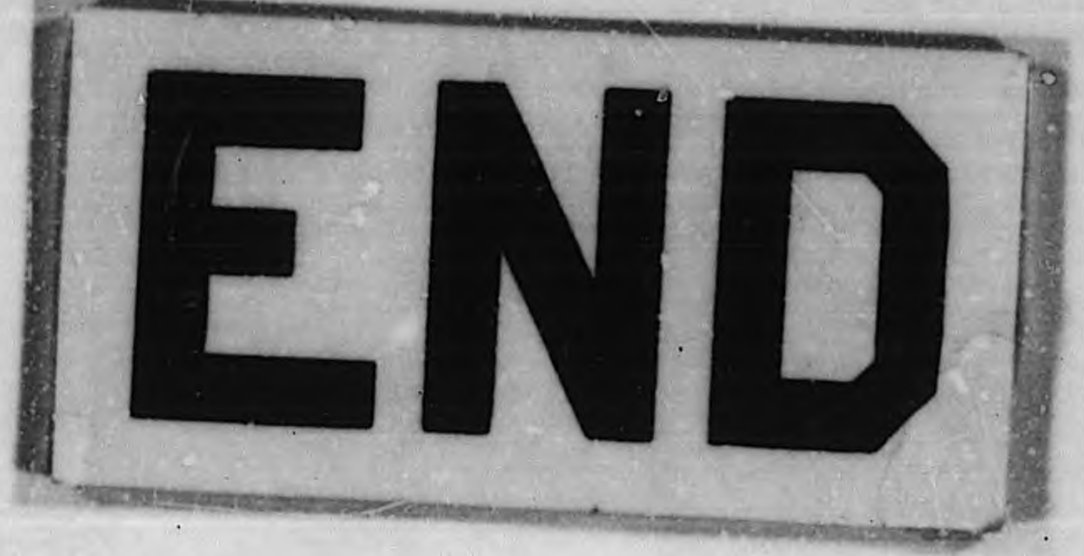

